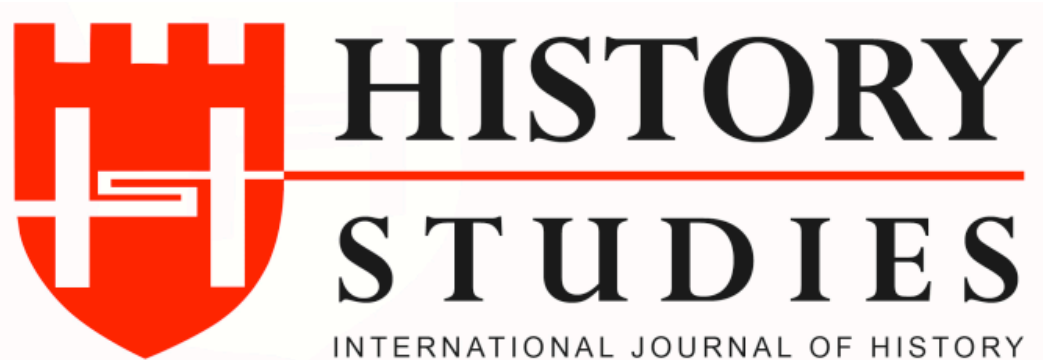

\author{
ISSN: 13094173 (Online) 1309 - 4688 (Print) \\ Volume 11 Issue 5, October 2019 \\ DOI Number: 10.9737/hist.2019.772 \\ Araştırma Makalesi
}

Makalenin Geliş Tarihi: 04.09.2019 Kabul Tarihi: 08.10.2019

Atıf Künyesi: Necdet Aysal - Ahmet Avcı, “Cumhuriyet Döneminde Kültürel Değişimin Bir Simgesi:

Ankara Etnografya Müzesi", History Studies, 11/5, Ekim 2019, s. 1433-1455.

\title{
Cumhuriyet Döneminde Kültürel Değişimin Bir Simgesi: Ankara Etnografya Müzesi
}

\author{
A Symbol of Cultural Change in the Republican Era: \\ Ankara Ethnography Museum
}

Doç. Dr. Necdet Aysal - Ahmet Avcı

ORCID No: 0000-0001-9574-6208 / 0000-0002-3105-7849

Ankara Üniversitesi

\begin{abstract}
Öz
\end{abstract}
Müzeler, geçmiş ve gelecek arasında taşıyıcılık yapan, geçmişin hatıralarını saklayıp teşhir eden ve bunları bilimsel olarak tanıtan kurumlardır. İmparatorluktan bir ulus devlete dönüşen Türkiye Cumhuriyeti'nin ilk yıllarında başkent Ankara'da temelleri atılan Etnografya Müzesi, kültürel ve mimari değişimin bir simgesi olmuştur. Milli kültür ve milli kimlik düşüncesi için gerekli olan bütün eşyayı bünyesinde barındıran müze binası, Atatürk'ün naaşına da uzunca bir süre ev sahipliği yapmıştır.

$\mathrm{Bu}$ çalışmada başta Başbakanlık Cumhuriyet Arşivi olmak üzere, birinci ve ikinci el kaynaklar ve basından yararlanılarak, Ankara Etnografya Müzesi'nin kuruluş süreci ele alınacak, Müze binasının yapımı ve tefrişi sırasında karşılaşılan zorluklar incelenecektir.

Anahtar Kelimeler: Ankara Etnografya Müzesi, Mustafa Kemal Atatürk, Gyula Meszaros, Hamit Zübeyr Koşay, Arif Hikmet Koyunoğlu, Nafiz Kotan.

\begin{abstract}
Museums are the institutions that carry the carrier between the past and the future, store and display the memories of the past and introduce them scientifically. Which has become a nation-state in the early years of the Republic of Turkey from the Empire, the capital foundations were laid in Ankara Ethnography Museum, it has become a symbol of the cultural and architectural changes. The museum building, which contains all the necessary goods for the idea of national culture and national identity, has also hosted Atatürk's body for a long time.

In this study, the establishment process of the Ankara Ethnography Museum will be discussed by using the first and second hand sources and the press, especially the Republican Archives of the Prime Ministry, and the difficulties encountered during the construction and furnishing of the museum building will be examined.
\end{abstract}

Keywords: Ankara Ethnography Museum, Mustafa Kemal Ataturk, Gyula Meszaros, Hamit Zubeyr Kosay, Arif Hikmet Koyunoglu, Nafiz Kotan.

\section{Giriş}


Cumhuriyet döneminde sosyal, mimari ve kültürel değişimin bir simgesi olarak planlanan Etnografya Müzesi, kültürel değerlerin saklandığı ve sergilendiği bir alan olmasının yanı sıra, milli ve millileştirilecek olan bütün düşüncelerin ilk uygulama sahası olmuştur. Başkent Ankara'da Cumhurbaşkanı Gazi Mustafa Kemal (Atatürk) Paşa'nın emir ve direktifleriyle kurulan ilk devlet müzesidir.

Yeni kurulan Türk Devleti'ni uluslararası toplulukta tanıtan Lozan Barış Antlaşması ile Türk Devrimi'nin silahlı eylem aşaması tamamlanmıştır. Bundan sonra yıkılan eski düzenin yerine yenisi kurulmaya başlanmış, sosyal hayatın icaplarına uygun olarak topluma ve yeni kurulan devlete şekil ve düzen verilmeye çalışılmıştır. Özellikle modern devleti kurmak için sosyal bünye değişikliği bir zorunluluk halini almıştır. Siyaset, hukuk, ekonomi, gündelik yaşam ve eğitim-kültür, alanlarında yapılan düzenlemelerle Türk toplumunun çağdaş uygarlıklar düzeyine yükseltilmesine çalışılmıştır. ${ }^{1}$

İmparatorluktan bir ulus-devlet modeline geçilirken, ulus kimliği için milli bir kültüre ihtiyaç duyulmuştur. Çünkü ulus-devlet yapısı, meşruiyeti için ulusal bir kimliğe muhtaçtır. ${ }^{2}$ Ulusun, her yeni doğan vatandaşının sosyalleşme sürecinde o toplumun belleğini alması, düşünüş, algılayış ve anlamlandırma biçimlerini öğrenmesi büyük önem taşımaktadır. $\mathrm{Bu}$ öğrenmeyi de başta okullar olmak üzere, müzeler, kütüphaneler, kültürel ve sanatsal faaliyetler gerçekleştirmektedir. ${ }^{3}$ Özellikle mekânsal düzenlemeler arasında yer alan "müzeler", kolektif kimliği inşa eden, biçimci ve bellek destekleyici araçlar olarak işlev görmektedir. ${ }^{4}$ Kültürün bütün unsurlarını bünyesinde barındıran ve sanatsal etkinliklerin yapıldığı alanlar olarak nitelendirilen müzeler, geçmiş ve gelecek arasında taşıyıcılık yapan, geçmişin hatıralarını saklayıp teşhir eden ve bunları bilimsel olarak tanıtan kurumlardır. ${ }^{5}$

\section{Osmanlı Devleti'nde Müzecilik}

15. yüzyılın sonlarından itibaren ortaya çıkan ve 1750 'lerden sonra yaygınlaşan müzeler, modernleşmenin bir göstergesi sayılmıştır. Özellikle Avrupa'daki önemli başkentlerde müzelerin açılması, Batılılaşarak modernleşmeye çalışan Osmanlıların dikkatini çekmiştir. Osmanlı Devleti'nde müzenin ilk oluşumu, Tanzimat döneminde Padişah Abdülmecit (18391861)'in Yalova seyahati sırasında gördügü Bizans yazıtlarını İstanbul'a getirtmesiyle başlamıştır. Bu eserler, 1846'da Osmanlı devlet adamı Tophane-i Âmire Müşiri Ahmet Fethi Paşa tarafından saray deposu olarak kullanılan Aya İrini Kilisesi'nde toplatılmıştır. ${ }^{6}$ Eski silahların toplandığı kısma "Mecmua-i Esliha-i Atika"” ve arkeolojik eserlerin toplandığı kısma

\footnotetext{
${ }^{1}$ Necdet Aysal, “Atatürk Dönemi Türk Devrimi”, Başlangıcından Günümüze Türkiye Cumhuriyeti Tarihi, (Editör, Prof. Dr. Temuçin Faik Ertan), 6. B., Siyasal Kitabevi Yay., Ankara 2018, s. 181.

${ }^{2}$ Kemal Çiftçi, "Tarih Kimlik ve Türkiye'nin Belleğinin Dış Politikası”, Akademik Incelemeler Dergisi, Sakarya Üniversitesi Sosyal Bilimler Enstitüsü, Cilt 2, Say1 1, Sakarya 2007, s., 102.

${ }^{3}$ Himmet Hülür, Gürsoy Akça, "İmparatorluktan Cumhuriyete Siyasal Bütünlük ve Ulusalcılık Söylemi”, Selçuk Üniversitesi Türkiyat Araştırmaları Dergisi, Sayı 22, Konya 2007, s. 315.

${ }^{4}$ Levent Cantek, "Kolektif Kimliğin İnşasında Halk Terbiyesi ve Ritüellerin Medya Metinlerine Dönüştürülmesi”, Folklor/Edebiyat, Uluslararası Hakemli Dergi, Cilt V, Say1 20, Ankara 1999, s., 10-11.

${ }^{5}$ Latince bir sözcük olan müze sözcüğü, kaynağını klasik Yunan mitolojisinde yer alan ilham perileri (mousai) müzlerden almıştır. Akıl, düşünce, yaratıcılık yeteneği anlamlarını taşıyan Müzler, sanatları koruyan dokuz tanrıçadır ve her biri şiir, müzik, tarih, dans gibi yaratıcı uğraşları korumakla görevlendirilmiştir. Bkz., Şefik Can, Klasik Yunan Mitolojisi, İnkılâp Kitabevi, İstanbul 1994, s. 64; Ferruh Gerçek, Türk Müzeciliği, Kültür Bakanlığı Yayınları, Ankara 1999,s. 11; Canan Dural Tasouji, "Bir Hafıza Mekânı Olarak Müze: Ankara Etnografya Müzesi”, Karadeniz Teknik Üniversitesi Illetişim Araştırmaları Dergisi, Yı1:3 Sayı 5-6, s. 131-132.

${ }^{6}$ Tahsin Öz, Ahmet Fethi Paşa ve Müzeler, Milli Eğitim Basımevi, İstanbul 1948, s. 1.

7 Askeri Müze olacaktır. Bkz., Halit Çal, “Osmanlı'dan Günümüze Türkiye'de Müzeler”, Türkiye Araştırmaları Literatür Dergisi, Cilt 7, Sayı 14, 2009, 317-319.
} 
ise "Mecmua-i Âsar-1 Atika" ad1 verilmiştir. ${ }^{8}$ Padişah Abdülaziz (1861-1876), 1867 y1lı yazında Paris, Londra ve Viyana'yı da içine alan bir yurt dışı seyahati gerçekleştirmiştir. Bu seyahat sırasında gezdiği arkeoloji müzelerinden etkilenmiş ve benzer bir müzenin İstanbul'da kurulmasını emretmiştir. Dönemin Sadrazamı Ali Paşa, Maarif Nezareti'ne bağlı bir imparatorluk müzesi kurmak için çalışmaları başlatmış ve adı geçen müze 1869'da Maarif Nazırı Safvet Paşa'nın girişimleriyle açılmıştır. "Müze-i Hümayun" olarak isimlendirilen müzeye, Galatasaray Lisesi öğretmenlerinden Britanya uyruklu Dr. Edward Goold, müdür olarak atanmıştır. ${ }^{9}$

1872 yılında iktidar değişikliği sonucunda, Ahmet Vefik Paşa'nın Maarif Nazırı olmasıyla Müze-i Hümayun müdürlüğüne tarihçi, arkeolog Alman Dr. Philipp Anton Dethier atanmıştır. Dethier döneminde ilk Asar-1 Atika Nizamnamesi hazırlanarak yürürlüğe girmiştir. 30 maddeden oluşan bu nizamnamede Osmanlı sınırları içerisinde bulunan tarihi nitelikli eserlerin yurt dışına çıkarılmasının önlenmesine yönelik hükümler yer almaktadır. ${ }^{10}$ "Osmanlı sınırları içerisinde nerede olursa olsun çıkarılan bütün eşyanın niteliği yazılı olarak bildirilecek ve izin verilmediği sürece çıkarılamayacaktır. Müzeye gerekli olduğu düşünülürse bedeli sahibinin rızası alınarak ödenecektir."

24 Nisan 1873 tarihinde Maarif Nazırı olan Ahmet Cevdet Paşa'nın yoğun çalışmalarıyla genişletilen Müze, Aya İrini'deki nem oranının yüksek olması ve eserlere zarar vermeye başlamasıyla 1875 yılında Çinili Köşk'e taşınmıştır. Burada kısa süre içerisinde eksiklikleri tamamlanan ve arkeolojik eserlerin sergilendiği müze, ilk kez halkın ziyaretine açılmıştır. ${ }^{11}$ Osmanlıda Müzeciliğin çağdaş anlamda gelişimine büyük katkı sağlayan Dr. Detheir'in 1881'de ölmesi üzerine, bu zorlu görev ressam ve arkeolog olan Osman Hamdi Bey'e verilmiştir. İlk Türk müze müdürü olan Osman Hamdi Bey, ülkedeki arkeolojik kazıların bir bölümünün Müze-i Hümayun tarafından gerçekleştirilmesini sağlamış ve girişimleri sayesinde müzedeki eser sayısı bir hayli artmıştır. ${ }^{12}$ Eser sayısındaki artış yeni bir müze binasının yapılmasını gündeme getirmiştir. Yeni Arkeoloji Müze binasının temelleri Çinili Köşk’ün karşısında atılmış ve Müze Müdürü Osman Hamdi Bey, bir yıllık maaşının tamamını müze inşaatı için bağışlamıştır. Yapılan bu yeni müze binasının ilk bölümü 1891, ikinci bölümü 1902 ve üçüncü bölümü ise 1908 yılında tamamlanmıştır. Yine Hamdi Bey döneminde resim, heykel ve mimarlık alanında uzman yetiştirilmesi amacıyla, müze idaresine bağlı "Sanayi Nefise Mektebi” adı ile Güzel Sanatlar Okulu açılmıştır. ${ }^{13}$

Osman Hamdi Bey'in 1910 yılında ölümü üzerine kardeşi Halil Ethem (Eldem) Bey Müze Müdürlüğüne getirilmiştir. Bu yeni dönemde Anadolu'da pek çok yerde kazılar yapılmış ve bulunan eserler müze salonlarına taşınarak teşhir edilmiştir. 1912’de Yıldız Çini Fabrikası

\footnotetext{
${ }^{8}$ Mustafa Oral, “Ankara Etnografya Müzesi İnkılâp Şubesi”, Atatürk Yolu Dergisi, Ankara Üniversitesi Türk İnkılâp Tarihi Enstitüsü, Sayı 29-30, Mayıs-Kasım 2002, s. 118.

${ }^{9}$ Müze Müdürü Dr. Goold'un 1871'de görevden ayrılmasıyla Sadrazam Ali Paşa'nın yerine geçen yeni Sadrazam Nedim Paşa, Müze Müdürlüğü'nü kaldırmış ve Aya İrini'deki eserleri korumakla Avusturyalı Trentzio isimli kişiyi görevlendirmiştir. Ancak bu değişiklik kısa sürmüştür. Bkz., İbrahim Serbestoğlu, Turan Açık, "Osmanlı Devleti'nde Modern Bir Okul Projesi: Müze-i Hümayun Mektebi”, Gazi Akademik Bakış, Cilt 6, Sayı 12, Yaz 2013, s. 161.

${ }^{10}$ Aziz Oğan, Türk Müzeciliğinin 100'üncü Yıldönümü, Türkiye Turing ve Otomobil Kurumu, İstanbul 1947, s. 8.

11 İstanbul Arkeoloji Müzesinin açılışı gerçekleşmiştir. Enver Behnan Şapolyo, Müzeler Tarihi, Remzi Kitabevi, İstanbul 1936, s. 32-33.

${ }^{12}$ Osman Hamdi Bey, birçok önemli arkeolojik kazılar yaptırmıştır. Sayda'da yapılan kazılarda Büyük İskender'in lahdi bulunmuş ve Çinili Köşke konmuştur. Adıyaman'da Nemrut dağı kazılarını bizzat kendisi yürütmüştür. Ayrıca müze nizamnamesindeki "tarihi nitelikteki eşyayı bulan yapancılara belli bir pay verilir" maddesini değiştirmiş ve bu sayede yurt dışına eser çıkarılması tamamen yasaklanmıştır. Bkz., Osman Hamdi, Hürriyet Gösteri Sanat Dergisi, Hürgün Gazetecilik ve Matbaacıllk A.Ş., İstanbul 1990, s. 1-32.

${ }^{13}$ Serbestoğlu, Açık, a.g.m., s. 167-168.
} 
müzeye çevrilmiş ve 1913'de Evkaf Nazırı Hayri Bey’in öncülüğünde İstanbul Süleymaniye'de, vakıf eşyalarını felaketlerden korumak amacıyla, Türk İslam eserlerini de içine alan bir "Evkaf-1 İslami’ye Müzesi” açılmıştır. Ayrıca Anadolu'nun çeşitli yerlerinde Müze-i Hümayun şubelerinin açılması gerçekleşmiştir. Halil Ethem Bey, müzeciliğin yaygınlaştırılması, bilimsel bir hüviyet kazanması ve bu çalışmaların Cumhuriyet döneminde de aynı heyecanla devam etmesine öncülük etmiştir ${ }^{14}$.

\section{Etnografya Müzesi'nin Düşünsel Temelleri}

Türkçe'de "rrkiyat" ve "halkbilim" olarak kullanılan Etnoloji, Latince "ethnos" 1rk veya kavim, "logia" teori veya bilim sözcüklerinin birleşmesinden oluşmaktadır. Etnoloji, farklı kültürlerin neden birbirine benzediğini ve neden farklılaştığını eşzamanlı ve artzamanlı olarak anlama çabasıdır. ${ }^{15}$ Kültürel bir varlık olarak insanı konu alan bu bilim dalı, Kıta Avrupa'sında etnoloji, Anglo-Sakson ülkelerinde sosyal ya da kültürel antropoloji ve Sovyetler Birliğinde ise etnografya olarak adlandırılmıştır. ${ }^{16}$ Etnografya, Yunanca Ethnos (halk) ve graphie (çizim) sözcüklerinin birleşiminden oluşmaktadır. Araştırmacıların görece küçük ölçekli, basit teknolojiye ve ekonomiye sahip, görece dış dünyadan tecrit olmuş topluluklara giderek oradaki bozulmamış kültürü kayda geçirme çalışmasıdır. ${ }^{17}$

Etnografya başta olmak üzere milli tarih ve dil anlayışının gerekliliği, 20. Yüzyıl başlarında Osmanlı İmparatorluğu'nun parçalanma sürecinin hız kazanması ve özellikle milliyetçilik fikirlerinin aydın ve asker kadrolarında benimsenmesi ile ortaya çıkmıştır. Bu bağlamda II. Meşrutiyetin ilanından sonra İstanbul'da 25 Aralık 1908'de “Türk Derneği” kurulmuştur. Derneğin kuruluş amacı nizamnamesinde, "Türk diye anılan bütün kavimlerin eski eserlerini, tarihini, lisanlarını, edebiyatını, etnografya ve etnolojisini, sosyal durumunu, yerleşik uygarlıklarını, eski ve yeni coğrafyasını araştırıp ortaya çıkarmak, bunu bütün dünyaya yaymak" şeklinde açıklanmaktadır. ${ }^{18}$

İlk milliyetçi kuruluş olarak kabul edilen derneğin kurucuları arasında Akçuraoğlu Yusuf, Necip Asım (Yazıksız), Rıza Tevfik (Bölükbaşı), Veled Çelebi (İzbudak), Beyler ve Mehmet Emin (Yurdakul), Hüseyin Cahit (Yalçın), Halit Ziya (Uşaklıgil) gibi birçok Türkçü yazarlar vardır. Dernek, amacı doğrultusunda kurs ve konferanslar düzenlemiş ve kendi adı ile bir dergi çıkarmıştır. Türk Derneği, Osmanlı sınırları dışında Macaristan'da Edebiyat-1 Osmaniye Cemiyeti adı ile bir şube de açmıştır. 22 üye ile açılan bu şubenin iki kâtiplik görevinden birini Gyula Meszaros üstlenmiştir. ${ }^{19}$ Türk Derneği, "Türk Yurdu Cemiyeti”nin kurulmasıyla çalışmalarını sonlandırmış ve üyelerinin büyük kısmı yeni cemiyete katılmıştır.

Türk Yurdu Cemiyeti, 31 Ağustos 1911 tarihinde Başta Mehmet Emin Yurdakul, Yusuf Akçura olmak üzere çoğu yurt dişı Türklerden oluşan Ahmet Hikmet Müftüoğlu, Ahmet Ağaoğlu gibi Türkçülük hareketinin önde gelen kişileri tarafindan kurulmuştur. Cemiyet, kendi

\footnotetext{
${ }^{14}$ Oğan, a.g.m., s. 6-19.

${ }^{15}$ Kudret Emiroğlu, Suavi Aydın, Antropoloji Sözlüğ̈̈, Bilim ve Sanat Yayınları, Ankara 2003, s. 164-166; Ahmet Avc1, Cumhuriyet Dönemi Etnografya Çalışmalarına Bir Örnek: Ankara Etnografya Müzesi”, (Ankara Üniversitesi Türk İnkılap Tarihi Enstitüsü, Basılmamış Yüksek Lisans Tezi), Ankara 2017, s. 13-14.

${ }^{16}$ Türkiye'de ilk kez 1940'larda Alman etkisinin yoğun olduğu Dil ve Tarih-Coğrafya Fakültesi’nde ders olarak verilmeye başlayan etnoloji, 1960'larda aynı fakültede ilk kez kürsü olarak da yine bu adla kurulmuştur. Bkz., Sedat Veyis Örnek, Etnoloji Sözlüğü, Ankara Üniversitesi Dil ve Tarih Coğrafya Fakültesi Yayınları, Ankara 1971, s. 8084.

${ }^{17}$ Antropoloji Sözlüğ̈̈, s. 283-284.

${ }^{18}$ Avc1, a.g.t., s. 29-30.

19 Gyula Meszaros, Ankara Etnografya Müzesi'nin kuruluşuna katkıda bulunacak ve müzede uzman olarak çalışacaktır. Bkz., Hüseyin Karaduman, "Türk Ocakları ve Hars Müzeleri”, Vakıflar Dergisi, Vakıflar Genel Müdürlüğü Yayınları, Sayı 30, Ankara 2007, s. 506.
} 
adıyla yayınladığı Türk Yurdu dergisi ile Türkçülük akımını çok derinden etkilemiştir. 30 Kasım 1911 tarihinde yayın hayatına başlayan derginin ilk sayısında amacı şöyle açıklanmaktadır: "Türklüğe hizmet etme, Türklere faide dokundurmak istiyoruz, maksadımız işte budur." Türk Yurdu dergisinin yayın nizamnamesinde de şu ifadelere yer verilmektedir: ${ }^{20}$

\begin{abstract}
"Türk ırkının mümkün olduğu kadar çoğunluğu tarafindan okunmak; Bütün Türklerce kabul edilecek bir ideal ortaya koymak; Türklerin birbiriyle tanışmaları için Türk dünyasının her tarafinda olup geçen ve bilhassa kardeşler arasında sevinç veya kedere sebep olan vakalar ile Türk dünyasının ötesinde berisinde ortaya çıkan fikir cereyanları kayıt olunacak, Türk ırkının muhtelif kavmiyetlerinde doğan edebiyatı ırkın bütün fertlerine bildirmek için çalışılacak; Osmanlı Türkleri arasında Türk milli ruhunun gelişme ve takviyesine, idealsizlikten doğan tembellik ve bedbinliğin giderilmesine çok çalışacak ve ekseriyet hiçbir şeye dayanmaksızın ortaya çıkan mübalağalı Batı korkusundan bu milleti elinden geldiği kadar uğraşacaktır."
\end{abstract}

Türk Yurdu dergisinin yayın nizamnamesinden anlaşılacağ 1 üzere Türkiye Cumhuriyeti'nin fikri temelleri Osmanlıda atılmıştır. Türklere ortak bir ideal aşılamak, Osmanlı Türkleri arasından dayanışmayı ve örgütlenmeyi artırmak, sade bir dil kullanmak ve bu çalışmalarının içeriğinin Türklere ait kültürel malzemelerle doldurulması kültürün uluslaştırılmasının bir bütünüdür. Türk Yurdu Cemiyeti'nin çalışmaları, Türk Ocakları'nın açılmasıyla son bulmuştur.

9 Mart 1912'de kurulan Türk Ocakları'nın kurucuları arasında, Ağaoğlu Ahmet, Mehmet Emin Yurdakul, Dr. Fuat Sabi Bey, Hüseyin Ragıp Bey, Tevfik Fikret ve Balkan Savaşları'ndan sonra oluşturulan yönetim kurulunda ise Hamdullah Suphi, Yusuf Akçura gibi isimler vardır. Cemiyet, Türklerin milli terbiye ve ilmi, iktisadi seviyelerinin yükseltilmesi ve yüceltilmesiyle Türk ırk ve dilinin mükemmelleşmesi yolunda çalışmalar yapacaktır. 1914 yılında yayınlanan nizamnamede ise Ocağın Türklüğe ve Türk kültürüne yönelik çalışacağı net olarak ortaya konulmuştur: $:^{21}$ “... Türklerin hars birliğine ve medeni kemaline çalışmak”

1918 yılında Türk ocakları bünyesinde Halide Edip, Hamdullah Suphi, Mehmet Emin Yurdakul, Mehmet Ziya Gökalp, Ağaoğlu Ahmet' Fuat Bey, Hüseyin Zade Ali Beylerden oluşan bir "Hars ve İlim Heyeti" oluşturulmuştur. ${ }^{22}$ Bu üyeler TBMM'nin açılması ile Maarif Vekâleti bünyesinde oluşturulan Hars Dairesi'nde de görev yapacaklardır.

Ziya Gökalp Yeni Gün gazetesinde yayımladığı, "Hars Teşkilatı" başlıklı yazısında; milli harsın gün yüzüne çıkartılması için milli müze ve etnografya müzesi gibi teşkilatlara ihtiyaç olduğunu vurgulamıştır: İstanbul Topkapı Sarayı Müzesi'ni medeni bir müze olarak niteleyen Gökalp, bu müzenin dışında yalnızca Türk harsına ait eserleri toplayacak milli bir Türk müzesine ihtiyaç olduğunu belirtmiştir. ${ }^{23}$

Türkiye'de etnografya çalışmaları, Birinci Dünya Savaşı'na kadar dilsel ve edebi çalışmalarla kendini göstermiştir. Bunlar ise genellikle etnografyanın adlandırılması ve bilimsel sınırlarının çizildiği yazılardır. Bununla birlikte Türkiye'de sistemli ve planlı Etnografya çalışmaları Türkiye Cumhuriyeti'nin kuruluşu ile başlamaktadır. 1923-1938 yılları arasında Türk kültürünü, tarih, folklor, dil ve etnoloji yönünden değerlendirmek amaciyla pek çok araştırma ve yayın yapılmıştır. ${ }^{24} \mathrm{Bu}$ dönemde Etnografya müzesi ve Milli müze açma çalışmaları ise Heyeti İlmiye toplantıları ile devam etmiştir.

\title{
3. Etnografya Müzesi’nin Kuruluşu ve Karşılaşılan Zorluklar
}

\footnotetext{
${ }^{20}$ Füsun Üstel, Imparatorluktan Ulus-Devlete Türk Milliyetçiliği Türk Ocakları, İletişim Yay, İstanbul 2004, s. 45.

${ }^{21}$ Avc1, a.g.t., s. 31-34; Üstel, a.g.e., s. 100.

${ }^{22}$ Tarık Zafer Tunaya, Türkiye'de Siyasal Partiler, Cilt1, İletişim Yayınları, İstanbul 2015, s. 458.

${ }^{23}$ Karaduman, a.g.m., s. 509.

${ }^{24}$ Orhan Acıpayaml1, "Türkiye'de Etnografi Araştırmaları", Etnografya ve Bilimsel Filmler Sempozyumu, 11-13

Nisan 1973, Avusturya Kültür Yayınları, İstanbul 1973, s. 5-6.
} 
Ankara'da Etnografya adı ile milli bir halk müzesinin kuruluş kararı, Milli Eğitim Bakanlığı'nın 15 Temmuz-15 Ağustos 1923 tarihleri arasında gerçekleştirdiği Birinci Heyet-i İlmiye Toplantısı'nda alınmıştır. Bu toplantıya Telif ve Tercüme Heyeti başkanı Ziya Gökalp başta olmak üzere, birçok tanınmış eğitimci ve sosyal bilimci katılmıştır. Bu geniş kadro, Milli Eğitimin bütün yönleriyle ele alınması için raporlar hazırlamış ve tavsiyelerde bulunmuştur. Yaklaşık bir ay süren bu toplantılarda ele alınan konular, yirmi yedi başlık altında görüşülmüş ve konu başlıklarıyla ilgili çeşitli encümenler oluşturulmuştur. Görüşülen konu başlıklarının dağılımına bakıldığında yaklaşık on başlığın kültür ve müze ile ilgili olduğu görülmektedir: ${ }^{25}$

\section{"1-Milli Hars, 2- Milli Bir Sözlük ve Dil Bilgisi kitabı hazırlanması, 3- Milli Müzik Milli Dil ve Edebiyat, 4- Milli Tarih Kütüphanesi, 5- Milli Evrak Hazinesi, 6- Milli Tarih ve Coğrafya Enstitüleri, 7- Etnografya Müzesi, 8- Milli Müze, 9- Okul Müzesi, 10- Eski Eserler Tüzüğünün Değiştirilmesi”"}

Birinci Heyet-i İlmiye Toplantısı esnasında oluşturulan Hars Encümeni Heyeti'nin başkanlığını Ziya Gökalp üstlenmiştir. O günlerde Heyet tarafından hazırlanan raporda, Milli Eğitim Bakanlığı'nın himayelerinde etnografya müzesi, halk müzesi, milli müze ve milli kütüphanenin kurulması istenmektedir. ${ }^{26}$ Alınan bu karar sonrası dönemin Milli Eğitim Bakanı Hamdullah Suphi (Tanrı̈̈ver) Bey, Budapeşte Etnografya Müzesi şeflerinden Macar Türkolog Prof. J. Meszaros'u müzenin kuruluşu için görevlendirmiştir ${ }^{27}$. 1 Şubat 1924 tarihinde göreve başlayan Meszaros'un hazırladığı 29 Kasım 1924 tarihli rapor, kurulacak olan müzenin kapsamı ve içeriği hakkında geniş bilgiler vermektedir. Etnoloji ve etnografyanın kapsamı ve tanımı ile başlayan rapor, halk müzelerinin dünyadaki örneklerine yer vermekte ve yeni kurulacak olan müzede öncelikle yapılması gereken işler şu şekilde sıralanmaktadır: ${ }^{28}$

$$
\begin{aligned}
& \text { “... Ankara'da kurulacak olan halk müzesi, bir millete ait olacă̆ için her şeyden evvel amacı } \\
& \text { Anadolu Türklerinin ilk devirlerden bu tarafa geçirdiği gelişim ve değişimini bilimsel metotlarla } \\
& \text { inceleyerek yapıp ettiklerini derlemek olacaktır... Bu sebeplerle öncelikle Ankara'da açılacak olan } \\
& \text { Halk Müzesinin bir mesai programı hazırlanmalıdır. Halk Müzesinin kuruluşu için ilk araştırmalar } \\
& \text { Anadolu'ya yapılacaktır. Müzeye ait olan eşyanın toplanması için bütün memurlar kıs gelene kadar } \\
& \text { çalışacaktır. Bu sürede toplamış olan eşyalar kataloglara kayıt edilecektir. Seyahat sırasında çekilmiş } \\
& \text { olan fotoğrafların kopyaları hazırlanacaktır. Bütün memlekette halk medeniyetine ait eşyalar } \\
& \text { toplanıldıktan sonra eşyanın esas halinden en az birer nüsha yapılacaktır. Halk müzesinin bu } \\
& \text { çalışmalarını ve koleksiyonların tanıtan bir dergi yayınlanmalıdır. Bu yayın Türkçe den başka ikinci } \\
& \text { bir dilde basılmalıdır. Aynı zamanda dünyada yayınlanan diğer memleketlere ait etnografya dergileri } \\
& \text { müze kütüphanesi için toplanmalıdır...” }
\end{aligned}
$$

Bu rapor çerçevesinde eser toplamak ve satın almak üzere İstanbul'da Prof. Celal Esad (Arseven) Bey ve 1925 yılında ise İstanbul Müzeler Müdürü Halil Ethem (Erdem) Bey başkanlığında özel komisyonlar kurulmuş ve çalışmalar başlatılmıştır. Prof. J. Meszaros'un hazırlayarak Milli Eğitim Bakanlığı'na sunduğu ikinci rapor, Ankara'da yapılacak müze binasının yeri ve özellikleri hakkında ayrıntılı bilgileri içermektedir: ${ }^{29}$
“...Halk müzesi milletin medeniyet hazinesini ihtiva eder ve ender eşi bulunmayan eşyayı muhafaza etmekle mükelleftir. Bu sebeple bu kıymetli eşyanın her türlü hava koşullarından ve rutubetten korunması zorunludur. Müze binası yüksek bir yerde inşa edilmelidir. Bu müze aynı zamanda bir eğitim kurumu olacăğından merkezden uzakta olmaması gereklidir. Müze salonlarının ve buralara yerleştirilecek eşyanın ışıklandırılması ve güneş ışı̆̆ının zararından da korunacak şekilde

\footnotetext{
25 Abdürrahim Güzel, "İlk Heyeti ilmiye Çalışmaları, Alınan Kararlar ve Dini Tedrisat", Erciyes Üniversitesi İlahiyat Fakültesi Dergisi, Sayı 4, Kayseri 1987, s. 340-341.

${ }^{26}$ Hars Encümeni Raporu, Hâkimiyet-i Milliye, 6 Ağustos, 1923, s. 1-3.

27 Yücel Namal, "Macar Türkolog Gyula Meszaros ve Türkiye'deki Çalışmaları”, XI. Milli Türkoloji Kongresi Bildiri Kitabı, C. 2, İstanbul Büyükşehir Belediyesi Kültür Daire Başkanlığı Yayınları, İstanbul 2015, s. 622-624.

28 "Ankara'da Teessüs Edecek Olan Halk Müzesi Hakkında Birinci Rapor", Maarif Vekâleti Mecmuası, Sayı 1, İstanbul 1 Mart 1341, s. 9-20; Avc1, a.g.t., s. 46-48.

${ }_{29}$ Ankara'da Teessüs Edecek Olan Halk Müzesi Hakkında İkinci Rapor”, Maarif Vekâleti Mecmuası, Sayı 4, İstanbul 1 Eylül 1341, s. 1-15.
} 
planlanması zaruridir. Müze binası bir kattan fazla olacă̆ muhtemel olduğundan ışılklandırma yan camlardan yapılmalıdır... Müze planları bir Türk mimarı tarafindan yapılıp, binanın eski ve hakiki Türk ve hatta lüzumu takdirinde şarklı Türk üslubunda inşa edilmesi uygundur."

Milli Eğitim Bakanlığı, bu rapor doğrultusunda Evkaf Umum Müdürlüğü (Vakıflar Genel Müdürlügü)'ne ait Numune (Gureba) Hastanesi'nin alt bölümünde yer alan ve Namazgâh Tepesi adıyla bilinen eski mezarlık alanın, müze inşaatı için kendilerine tahsis edilmesi için girişimde bulunmuştur. Adı geçen arsa, dini törenlerin (bayram namazları ve yağmur duaları) yapıldığı kutsal bir mekândır. ${ }^{30} \mathrm{Bu}$ esnada Vakıflar Genel Müdürlüğü, konum itibariyle şehir merkezi ile iç içe olan bu arsaya otel yapma düşüncesindedir. Ayrıca Müdafaa-i Milliye Vekâleti de (Milli Savunma Bakanlığı), adı geçen arsaya Erkân-ı Harbiye-i Umumiye Reisliği (Genelkurmay Başkanlığı) binası yapmak için talepte bulunmuştur. ${ }^{31}$ Yapılan inceleme ve değerlendirmeler sonucunda bu mekân, 15 Kasım 1925 tarihli Bakanlar Kurulu kararıyla müze yapılmak üzere Milli Eğitim Bakanlığı'na bağışlanmıştır. ${ }^{32}$ Milli Eğitim Bakanlığı, müze inşaatı için Prof. J. Meszaros'un hazırladığı raporları dikkate almış ve gerekli çalışmaları başlatmıştır. Özellikle Meszaros tarafından hazırlanan ikinci raporda, müze binasının yapımı hakkında şu uyarılar dikkat çekicidir: ${ }^{33}$

\begin{abstract}
“Müze, Türk ruhunun görünürlüğ̈nü ve bu günde kadar getirdiği medeniyetinin bütün safhaların bünyesinde barındıracağı için bütün özellikleriyle ile bir Türk eseri olmalıdır. Ankara'da şimdiye kadar inşa edilmiş olan yeni binalar gibi bu bina da diğerleri gibi Arabî bir üslup üzere yaplacak olursa, bu müzenin ruhuna ve amacına asla uygun olmayacaktır. Bu bağlamda müze planlarının bir Türk mimar tarafindan yapılması ve binanın eski ve hakiki Türk ve hatta lüzumu takdirinde şarklı Türk üslubunda inşa edilmesi uygundur."
\end{abstract}

Bakanlık, bu raporlar doğrultusunda mimar konusunu çözmek üzere çalışmalarını hızlandırmıştır. Binanın yapımı için bir şartname taslağı hazırlanmış ve bazı Türk mimarlarla görüşmeler yapılarak konuyla ilgili proje hazırlamaları istenmiştir. Bu esnada Milli Eğitim Bakanlığı, Ankara'da Mimar Arif Hikmet (Koyunoğlu) Bey'le bağlantıya geçmiştir. Arif Hikmet Bey, anılarında bu görüşmeden şöyle bahsetmektedir: $:^{34}$

\begin{abstract}
"Bir gün (1925 yılı) Maarif Vekâleti’ne çağırdılar. Eski bazı eserler İstanbul'dan Ankara'ya getirilmiş ve Mevlana Camii denilen yere depo edilmiş, orada harap oluyorlarmış, bunların muhafaza ve teşhiri için bir bina yaptırmay düşünüyorlarmıs. Kendi fen heyetleri ve bazı mimarlar proje vermişler. Sende bir proje hazırla dediler ve şartnameyi verdiler. Binanın eski Türk mimarisine uygun olmasın istiyorlardı. Projeyi yaptım ve incelemeler sonunda kabul edildiğini söylediler."
\end{abstract}

Arif Hikmet Bey, kendisine verilen şartnameye uygun olarak on beş gün içerisinde projesini teslim etmiştir. Milli Eğitim Bakanlığı, müze binası için hazırlanan projeler arasından Arif

\footnotetext{
${ }^{30}$ M. Şakir Ülkütaşır. Cumhuriyet'le Birlikte Türkiye'de Folklor ve Etnografya Çalışmaları, Başbakanlık Basımevi, Ankara 1972, s. 45.

${ }^{31}$ Milli Savunma Bakanlığı, yapmış olduğu incelemelerde arsanın inşaata uygun olmadığını görerek bu talebinden vazgeçmiştir. Bkz., ${ }^{31}$ Hüseyin Karaduman, Ulus-Devlet Bağlamında Belgelerle Ankara Etnografya Müzesi'nin Kuruluşu ve Milli Müze, Bilgin Kültür Sanat Yayınları, Ankara 2016, s. 96.

321926 yılında Etnografya Müzesi inşaatının bulunduğu araziden, Tayyare Cemiyeti ve Türk Ocakları'na bina yapılabilmesi için pay verilmiştir. Nitekim adı geçen arsanın küçüldüğü ve yalnızca müze binasını içinde barındıran bir alan kaldığı görülmektedir. Bkz., Karaduman, a.g.e., s. 98.

33 “Ankara'da Teessüs Edecek Olan Halk Müzesi Hakkında İkinci Rapor”, Maarif Vekâleti Mecmuası, Sayı 4, İstanbul 1 Eylül 1341, s. 1-15.

${ }^{34} \mathrm{Bu}$ eserler Topkapı Sarayından Ankara'ya getirilen kutsal emanetlerinden içinde bulunduğu değerli eserlerdir. Türk ordusu İstanbul'a girdikten sonra tekrar yerlerine gönderilmişlerdir. Bkz., Hasan Kuruyazıcı, Osmanlı'dan Cumhuriyet'e Bir Mimar Arif Hikmet Koyunoğlu Anılar, Yazılar, Mektuplar, Belgeler, Yap1 Kredi Yayınları, İstanbul 2008, s. 242.
}

\title{
History Studies
}


Hikmet Bey'in projesini uygun bulmuştur. ${ }^{35} \mathrm{Bu}$ arada başlayacak olan müze inşaatının müteahhitliği ise Erzurumlu Nafiz (Kotan) Bey'e verilmiştir. ${ }^{36}$ Nafiz Bey, yanına bir mühendis alarak çalışmalara başlamıştır. Milli Eğitim Bakanlığı'nın öncülüğünde ve Maliye Bakanlığı'nın destekleriyle başlayan Müze inşaatının temeli, 25 Eylül 1925'te Namazgâh Tepesi'nde atılmıştır. Müze temeline ilk taş Başbakan İsmet (İnönü) Paşa tarafından konulmuş ve dönemin Maarif Vekili Hamdullah Suphi (Tanrı̈ver) Bey şu konuşmayı gerçekleştirmiştir: ${ }^{37}$

\begin{abstract}
“... Beşeriyetin en asil ve en ulvi göründüğü köşe müzelerdir. Müzeler milletlerin ve dinlerin sanat ve tarih önünde aynı huşu hissiyle birleştiği yerlerdir. Müzeler terbiye müesseslerimiz için muhtaç olduğumuz vasitalardandır. Bunun içindir ki Cumhuriyet günlerinden beri memleketin her köşesinde tarih ve sanat yadigârların korumakla, toplamakla ve halkın istifadesine arz etmekle meşgulüz. Topraklarımızda Türkiye'yi mesela İtalya gibi baştanbaşa bir müze haline koyacak defineler vardır. İstiyoruz ki Türk Vatanının her köşesi yeni Türk nesillerinin duyduğu ihtiyacı tatmin edebilsin... Eski yeni, acı, tatlı birçok müessir hatıraların izlerine taşıyan Ankara'mızda Devlet Müzesi'nin ilk temel taşını atıyorum ve hayalim memleketin diğer köşelerinde birbirini takip edecek bu gibi ilim, sanat ve tarih amillerinin yükseldiğini tahassürle seyrediyor."
\end{abstract}

Cumhuriyetin ilk yıllarında Anadolu'nun ortasında, bir bozkır kasabasında başlayan müze binasının yapım aşaması oldukça zorlu geçmiştir. Nitekim çekilen maddi ve manevi zorlukların ne derece büyük olduğu, Mimar ve Müteahhidin yakınmalarından anlaşılmaktadır. Ankara'da taş ve demirci ustalarının bulunmaması, inşaat için gerekli çimentonun Fransa'dan getirtilmesi, Ayaş yakınlarında küfeki taş ocakları ve Marmara'daki mermer ocaklarından çıkarılan malzemenin Ankara'ya taşınması pek çok sıkıntıyı beraberinde getirmiştir. ${ }^{38}$ İstanbul'dan Ankara'ya getirilen mermer taş ustalarının başında Hüseyin Avni Bey vardır. O'nun ortağı olan Karagöz-zade Salih Sabri Bey ise Marmara'daki mermer ocaklarından inşaat için gerekli olan mermer taşları çıkartıyor, yelkenli ile Haydarpaşa'ya getiriyor ve oradan da trenle Ankara'ya gönderiyordu. Özellikle taşıma esnasında kamyon ve vinç gibi vasıtaların bulunmaması, bu mermer ve taş blokların Ankara'daki inşaat alanına götürülmesi gecikmelere neden olmuş ve çalışmaları yavaşlatmıştır. $\mathrm{Bu}$ esnada yaşanan sorunları Nafiz Bey şu şekilde dile getirmektedir: $^{39}$

\begin{abstract}
“...Marmara'dan trenle gelen mermer blokları, vagon üzerine yaptığımı ahşap rampadan kaydırarak domuz arabası dediğimiz alçak demir tekerlekli arabalara yüklüyorduk. Bu arabaları dört çift öküz arabasına bağlayıp amele ve vatandaşların yardımı ile taşıyorduk. ... Inş̧aat duvarı yükseldikçe işler de zorlaşıyordu. Koca taşlar hep insan kuvveti ile çıkarlliyordu..."
\end{abstract}

Müze binasından kullanılan mermerlerin bir kısmı yurt dışından özellikle İtalya'dan getirtilmiştir. 1926 yılı başlarında Marmara Adası ve İtalya'dan temin edilen mermer taşlardan bazılarının sevkiyat sırasında kırılması ve yeniden sipariş edilmesi, son derece ağır olan müze

\footnotetext{
35 İlk projede müze binasının numune hastanesine doğru genişletilmesi planlanırken iken, sonradan araya kız lisesinin girmesiyle buna imkân kalmamıştır. Bkz., Nurcan Fırat İnci, Ankara'da Cumhuriyet Dönemi Mimarisinden İki Örnek Etnografya Müzesi ve Eski Türk Ocağı Merkezi Binası, Türk Tarih Kurumu Basımevi, Ankara 1998, s. 21.

${ }^{36}$ İstanbul'da müteahhitlik yapan Erzurumlu Nafiz (Kotan) Bey, Ulusal Bağımsızlık Savaşı'nda kendi imkânlarıyla satın aldığı 4 uçağı orduya hediye etmiş ve yine ordu için gerekli birçok malzemeyi Anadolu'ya göndermiştir. İstanbul'un resmen işgali sırasında tüm mal varlığını satarak Ankara'ya yerleşmiştir. Ankara'da birçok büyük yapının müteahhitliğini üstlenmiştir. Nafiz Bey, yapmış olduğu bu yardımlarla Atatürk'ün de dikkatini çekmiş̧tir. Bkz., Karaduman, a.g.e., s.102.

${ }^{37}$ Cumhurbaşkanlarl, Başbakanlar ve M.E. Bakanlarının Milli Eğitimle İlgili Söylev ve Demeçleri, Milli Eğitim Basımevi, Ankara 1946, s. 341, 342; Tasouji, a.g.m., s. 139; Avc1, a.g.t., s. 54-55; Oral, a.g.m., s. 119.

${ }^{38}$ Bina diş cephelerinde kullanılacak olan Küfeki taşı, Ankara'ya $40 \mathrm{~km}$ mesafede bulunan Ayaş'ın Lezgi isimli köyünde bulunan taş ocaklarından temin edilmiştir. Bu blok taşları çıkarabilmek için Marmara Adası'ndan taş ustaları getirtilmiş ve bu ustalar tarafından çıkarılan ve kabası düzeltilen taşlar, kağnı arabalarıyla Ankara'ya nakledilmiştir. Bkz., Kuruyazıcı, a.g.e., s. 244.

${ }^{39}$ Güven Birkan, Selçuk Pehlivanll, "Mimar Arif Hikmet Koyunoğlu ile Bir Söyleşi”, Mimarlık Dergisi, Sayı, 150, İstanbul 1977, s. 10; Kuruyazıc1, a.g.e., s. 244.
} 
merkez kubbesinde kullanılan betonarme direklerin soğuk hava koşullarından dolayı tamamen donması gibi olumsuzluklar, Müteahhit Nafiz Bey'in inşaat için ek süre istemesine yol açmıştır. Yapılan bu müracaat Maarif Vekâleti tarafından uygun görülmüş ve inşaat süresinin Kasım 1926 tarihine uzatılması kabul edilmiştir. ${ }^{40}$ İnşaat çalışmaları devam ederken Maarif Vekâleti, Başvekâlete gönderdiği bir dilekçede müze binasının betondan yapılması tasarlanan bir kısım yerlerin özellikle mermer sütunların dayandığı zeminin ve kubbenin altına denk gelen yerlerin mermer olmasının estetik açıdan gerekli olduğunu bildirmiş ve 10.644 liralık ek ödenek talebinde bulunmuştur. ${ }^{41}$ Bu talep Başvekâletçe incelenmiş ve Kasım 1926 tarihli bir kararname ile bu değişikliğin sergilenecek eşyanın teşhiri ve estetik açısından gerekli olduğu kabul edilmiştir. ${ }^{42}$ Nitekim mermerle kaplanmak üzere ek ödenek ayrılan bu bölüm Atatürk'ün geçici istirahatgâhı olacaktır. Hamit Zübeyr (Koşay) Bey, hatıralarında bu alanın mermerle kapatılması fikrini Cumhurbaşkanı Mustafa Kemal Paşa'nın verdiğini söylemektedir: ${ }^{43}$

\begin{abstract}
"Bir Pazar günü Atatürk ansızın müze binasına geldi, giriş karşısında ki kubbenin altında erken dönem Osmanlı cami mimarisinde olduğu gibi etrafi çakıl taşlarlyla dekore edilmiş bir şadırvan vardı. Atatürk bu şadırvanı görünce, bunun kaldırılarak buranın da mermerle kaplanmasını emretti. Atatürk diğer salonları da gezdi ve bazı talimatlar verdi. Ben bütçe imkânsızlıklarından bahsettiğimde, kaç para istiyorsun dedi, 5000 TL dedim. Ertesi gün yaverle gönderdi."
\end{abstract}

Müze inşaat çalışmaları, dönemin bütün bu olumsuz koşullarına rağmen devam etmiş ve 1927 yılının yazında tamamlanmıştır. 12 Aralık 1926 tarihli Başvekâlet tarafından yayınlanan bir kararnamede müze inşaat bedelinin beş taksitle ödeneceği ve son taksitin ise inşaat bittikten sonra verileceğine dair bilgi mevcuttur. ${ }^{44}$ Bina, mimar Arif Hikmet Bey'in hazırlamış olduğu şartnameye uygun olarak yaklaşık $854 \mathrm{~m}^{2}$ bir alan üzerinde inşa edilmiştir. Dikdörtgen şeklinde, açık avlulu ve tek kubbelidir. Kesintili bir bodrum kat üzerinde önde tek katlı müze, arkada iki katlı idari kısım olmak üzere iki bölümden oluşmaktadır. Yapının, duvarları küfeki taşı ve alınlık kısmı, merdivenler ve döşemeler ise mermerle kaplanmış olup oyma süslüdür. Binaya 28 basamaklı bir merdivenle çıkılmakta ve kapıdan girişte önce kubbe altı holüne ve buradan da iç avlu denilen sütunlu kısma geçilmektedir. ${ }^{45}$ Buraya mermer bir havuz yapılmış ve çatı kısmı açık bırakılmıştır. [Bu iç avlu 1938'de Atatürk'e geçici kabir olarak ayrıldığında, havuz bahçeye nakledilerek, çatısı kapatılmıştır] İç avlunun etrafinda simetrik olarak büyüklü küçüklü salonlar yer almaktadır. Yapı, ön cepheye demir parmaklıklı dikdörtgen sekiz pencere ile açılmaktadır.

\title{
4. Etnografya Müzesi'nin Tefriş Çalışmaları
}

İnşaatın tamamlanmasından sonra bina, Meszaros'un hazırladığı raporlar doğrultusunda düzenlenmeye başlamış ve Halil Ethem Bey başkanlığında kurulan komisyon tarafından müze için satın alınan 1250 eser, İstanbul'dan bu binaya getirilerek yerleştirilmiş̧ir. 1 Haziran 1927'de ise Etnografya Müze Müdürlüğü’ne, eski Kültür Müdürü Dr. Hamit Zübeyr (Koşay) Bey atanmıştır. Aynı yıl Milli Eğitim Bakanlığı tarafından müzenin önüne konulması için Mustafa Kemal Paşa'yı omuzunda pelerini ile at üzerinde gösteren büyük bir bronz heykel yaptırılmıştır. İtalyan Heykeltıraş Pietro Canonica tarafından yapılan bu Atatürk heykeli, 4 Kasım 1927'de Başbakan İsmet (İnönü) Paşa'nın da katıldığı büyük bir törenle açılmıştır.

\footnotetext{
${ }^{40} B C A ., 30.18 .01 .01 .21 .67 .14$; Bkz., EK-1.

${ }^{41} B C A ., 30.18 .01 .01 .22 .76 .17$.

${ }^{42}$ BCA., 30. 18. 01. 01. 21. 67. 9.

${ }^{43}$ Avcı, a.g.t., s. 57; Sadi Bayram, "Hamit Zübeyr Koşay’dan Anekdotlar”, Türk Kültürü Araştırmaları Dergisi, Türk Kültürü Araştırma Enstitüsü, C. XXIV, Sayı 2, 1986, s.12.

${ }^{44}$ BCA., 30.18.1.1.22.76.17; Bkz., EK-2.

${ }^{45}$ Ankara Üniversitesi Türk Inkılap Tarihi Enstitüsü Arşivi (TITE), FK76, G2, B2-141001; Bkz., EK-3.
} 
Cumhuriyet döneminde Ankara'ya yapılan ilk anıt olma özelliğini taşıyan bu heykel, aynı zamanda Heykeltıraş Canonica'nın da ilk eseridir. ${ }^{46}$

Açılış hazırlıklarının devam ettiği günlerde 15 Nisan 1928 yılında Etnografya Müzesi'ni ziyaret eden Gazi Mustafa Kemal Paşa, müze hakkında yetkililerden bilgi almış ve Mayıs ayı içerisinde Afgan Kralı Amanullah Han'ın Türkiye'yi ziyaretleri sebebiyle, müzenin hizmete açılmasını istemiştir. ${ }^{47} \mathrm{O}$ tarihlerde İstanbul'daki yabancı elçiliklerin başkent Ankara'ya taşınması söz konusu olup İngiliz Büyükelçiliği ise İstanbul'dan ayrılmayacağını dile getirmektedir. Böyle bir krizin yaşandığı ortamda başkent Ankara'yı ilk kez bir devlet başkanının ziyaret etmesi son derece önemli bulunmuştur. Mustafa Kemal Paşa'nın emir ve direktifleriyle hazırlıklara başlanmış, ana yollar ağaçlandırılmış ve misafirlerin konaklayacağ Ankara Palas'ın eksiklikleri kısa süre içerisinde tamamlanmıştır. ${ }^{48} 17$ Nisan 1928 tarihinde görkemli bir törenle açılan bu tarihi bina, başkent Ankara'nın ilk modern oteli ve balo salonudur. Ankara Palas, şehre gelen önemli yabancı diplomatik misafirleri ve şehirde yaşayan yeni elitleri, bürokratları ve aydınları ağırlayan vazgeçilmez bir sosyal mekân olarak işlev görmüştür. ${ }^{49}$

Maarif Vekâleti, Afgan Kralı'nın Ankara'ya teşrifleri nedeniyle Etnografya Müzesi'nin noksanlıklarının acilen belirlenmesi ve bunların hızlı bir şekilde tamamlanabilmesi için 25 Nisan 1928 tarihinde Yüksek Tedrisat Umum Müdürü Rüştü Bey'in başkanlığında bir komisyon kurmuştur. Komisyon üyeleri arasında Müzeler Müdürü Mübarek Bey, Halk Terbiyesi Müdürü Faik Reşit Bey, Mektep Müzesi Müdürü İsmail Hakkı Bey, Ankara Asar-1 Atika Müzesi Müdürü Hakkı Baha Bey ve Ankara Etnografya Müzesi Müdürü Hamid Zübeyr Bey yer almaktadır. "İhzâr Komisyonu” olarak bilinen bu komisyona, Afgan Kralı'nın misafir edilmesi için ayrılan ödenekten 5.000 Lira harcayabilme yetkisi verilmiştir. ${ }^{50}$ Ancak Müzenin noksanlıklarını tamamlamak üzere ayrılan bu para, kanuni işlerden dolayı hemen çekilememiş ve harcanamamıştır. İhzar Komisyonu ise işlerin çokluğunu ve zamanın darlığını göz önüne alarak, bankadan üç bin lira ödünç alma yoluna gitmiştir. ${ }^{51}$

Etnografya Müzesi Müdürü Hamit Zübeyr Bey, 26 Nisan 1928 tarihinde Maarif Vekâleti'ne müzenin açılışı için gerekli olan malzemelerin listesini göndermiştir. Ankara ve İstanbul'dan satın alınacak malzemeler şeklinde hazırlanan liste için komisyon çalışmalara başlamış ve İstanbul'dan alınacaklar için Uzman Meszaros ile levazım memuru Hüsnü Bey görevlendirilmiştir. İstanbul'dan temin edilecek olan ihtiyaç listesinde şu objeler yer almaktadır: ${ }^{52}$

\begin{abstract}
"Kastamonu kadın klyafetlerinden ayakkabı, çorap, başlık, iç gömlek, siyahî kuşak; Aydın kadın klyafetinden başlık, ayakkabı, çorap, kırmızı kuşak, gerdanlı; Kürt gelin kıyafetinden başlık, don, kuşak, çorap, ayakkabl, gerdanlık; Mevlevi klyafetinden ayakkabl, kuşak; Bektaşi klyafetinden; Laz klyafetinden zıpka, siyah pantolon, gölek, kollu ceket, ayakkabı, çorap, kuşak; Gelin kıyafetlerinden ayakkabı iki adet, kuşak, fes, gömlek; Etnografya Müze levhası 62 X 80 ebadinda ve $20 X 30$ ebadında da 16 adet levha; Kalın kaytan 100 metre, ince kaytan 250 metre; Sandalye, koltuk ve kanepeler takriben kırk adet; Palmiyeler; Fon için bazı ince kumaşlar; Raptiye, tel firçalar, boyalar, yağlı boya
\end{abstract}

\footnotetext{
${ }^{46}$.Ü. Aylin Tekiner, Atatürk Heykelleri, Kült, Estetik, Siyaset, İletişim Yayınları, İstanbul 2010, s. 79-86.

${ }^{47}$ Bayram, a.g.m., s. 12.

${ }^{48}$ Bilal N. Şimşir, Atatürk ve Afganistan, Avrasya Stratejik Araştırmalar Merkezi Yayınları, Ankara 2002, s. 160.

49 Atatürk'ün direktifleriyle 1924 yılında yapımına başlanan bu tarihi binanın mimarı Vedat (Tek) Bey'dir. Ancak inşaat devam etmediği için 1926 yılında mimar Kemalettin Bey devralmıştır. Kemalettin Bey ise 1927 yılında şantiyede vefat etmiştir. Bkz., Ahu Sunbas, “Türk Modernleşmesi'ni Ankara Palas Üzerinden Okumak: Doğu'dan Batı'ya Açılan Bir Pencere", H. Ü. İktisadi ve İdari Bilimler Fakültesi Dergisi, Cilt 31, Sayı 1, 2013, s. 181.

${ }^{50}$ Avc1, a.g.t., s. 60-61; BCA., 180.09.31.166.1.53; Bkz., EK-4.

${ }^{51}$ Kanuni işlerin tamamlanması ve ödeneğin açılmasıyla bu borç kapatılmıştır. Bkz., $B C A$., 180.09.31.166.1.64.

${ }^{52}$ BCA., 180.09.31.166.1.63; BCA., 180.09.31.166.1.46; BCA., 180.09.31.166.1.47; Bkz., EK-5-6.
}

\title{
History Studies
}


firçaları, çini mürekkebi ve yağlı boya; Numaratör; Toz emen makine; Yangın söndürme aleti; Telli yuvarlak etiketler, kitap etiketleri; Şırınga halılarla mensucatın temizlenmesi için; Mirban yağı için ufak şişeler elli adet; Resim Müzesi için ufak halkalar; Agrandisman kâğtları ile banyosu; iki adet manken"

Komisyon öncelikle Ankara'dan satın alınacak malzemenin temini için çalışmalara başlamıştır. Bu malzemeler arasında şu eşyalar bulunmaktadır: ${ }^{53}$

\begin{abstract}
"Kereste, kaideler için takriben 100 liralık; Gardırop için Bronz askılar; Yağgl boya, tutkal, kontrplak, çivi; Teller, çini teşhiri için; Perde; Muşamba (linolyum); Levhaları asmak için demir tertibat; Marangoz yevmiyesi; Çıkabilecek ek masraflar (hamaliye, etiket, hattat, bayrak, mukavva); Nakliye; Hademe elbisesi üç takım (biri kadın için; ceket, şapka, fistan, ayakkabı); Karpit feneri (bir çeşit gaz); İç avludaki bahçenin yeşillendirilmesi"
\end{abstract}

21 Nisanda malzeme listesindeki gardırop ve diğer ahşap tertibatın yapım işi, dört buçuk lira yevmiye ile İsmail ustaya verilmiştir. Ancak ustanın zaman darlığı yüzünden istenilen işleri zamanında yetiştiremeyeceği anlaşıldığından yanına iki ve üç lira yevmiye iki kalfanın daha çalıştırılmak üzere görevlendirildiği 26 Nisan 1928 tarihli belgede görülmektedir. ${ }^{54}$ Yine aynı tarihli belgede müzeye lazım olan otomatik telefonun, yüz on iki buçuk liraya temin edildiği ve ücretinin ödenmesi rica edilmektedir. ${ }^{55}$ Müze salonlarında sergilenecek tablolar için gerekli demir tertibatın yapılması için Ankara Sulu Han esnafından Demirci Hüseyin Habib Usta bir teklif vermiştir. Toplam 279 lira tutarındaki bu teklif komisyonca kabul edilmiş ve işin tamamlanmasının ardından Hüseyin Habib Usta'ya 5 Mayıs 1928 tarihinde toplam 293.50 kuruş ödeme yapıldığı görülmektedir. ${ }^{56}$ Ustaya, bu işlerin yanı bazı ek işler ve bir merdivenin de yaptıııldı $\breve{g} 1$ resmi belgelerden anlaşılmaktadır. ${ }^{57}$

Müzelik eşyaların sergilenebilmesi için bina içerisinde düzenlemeler yapılırken, bir yandan da temizlik işleri başta olmak üzere bazı hizmetlerin yapılabilmesi için eleman ihtiyacı ortaya çıkmıştır. Müze Müdürlüğü, 8 Mayıs 1928 tarihinde Maarif Eminliği’ne gönderdiği yazıda, müzede hali hazırda üç görevlinin (hademenin) bulunduğunu ve bunlardan bir tanesinin ise gece bekçisi olarak istihdam edildiğini açıklamaktadır. Bu bağlamda müzenin açılışında, sekiz salonun iki görevli ile temsil edilmesinin mümkün olamayacağını ve acil olarak personel takviyesine ihtiyaç bulunduğunu dile getirmektedir. Aksi halde Müze Müdürlüğü olarak hiçbir mesuliyetin kabul edilmeyeceği belirtilmiş ve müzenin gerekli personel ihtiyacı şu şekilde verilmiştir: "S8 "Salonlar için sekiz kişi, Gardırop için bir muhafız ve bir gece nöbetçisi olmak üzere toplam 10 kişidir."

İhzâr Komisyonu, 12 Mayıs 1928'de Etnografya Müzesi'nin kapısına asılacak 62/80 ebadında pirinç levhayı, yüz elli lira bedel karşıllığında tabelacı Hayri Efendiye yaptırmıştır. ${ }^{59}$ $\mathrm{Bu}$ esnada İstanbul'dan satın alınacak malzemeler için görevlendirilen İstanbul Maarif

\footnotetext{
${ }^{53} B C A$., 180.09 .31 .166 .1 .47 .

${ }^{54} B C A$., 180.09 .31 .166 .1 .48 .

${ }^{55} B C A$., 180.09 .31 .166 .1 .42 .

${ }^{56}$ Hüseyin Habib Ustanın teklifi şöyledir: 1 Alt salona yüz seksen altı metre tülünde 1.1/4 parmak kalınlığında demir boru kullanılacak ve uçları T şeklinde duvara monte edilecek. Duvar alçı ve har ile düzenlenecek. 2 Her duvara sathındaki boru üzerinde yirmi beş adet ağır yüke dayanıklı çengelli halka takılacaktır. 3 Her duvara takviye için kroșeler konacaktır. 4 Borular ve çengeller evvelce kırmızıya sonra yağlı boya ile beyaza boyanacaktır. 5 Bu işçilik ve duvarlara yapılanların tamiri müteahhide ait olacaktır. 6 Beher metrenin malzeme fiyatı dâhil olduğu halde, ,maliyet için 1,5 lira yani toplam 1,5x186= 279 lira talep olunacaktır. Bkz., BCA., 180.09. 31.166.1.37; Bkz., EK-7.

${ }^{57}$ Hüseyin Habib Ustaya merdiven yapımı için 24 lira ödenmiştir. Bkz., BCA., 180.09. 31.166.1.18; BCA., 180.09. 31.166.1.16.

${ }_{58}^{5}$ Müze Müdürü Hamit Zübeyr Bey’in kadro isteği yerine getirilememiştir. Bunun üzerine Müdürlük 24 May1s 1928 tarihli yazıyla hademe İbrahim ve Yunus Beylerin geçici olarak bir ay süreyle çalıştırılmalarını istemiştir. Bkz., $B C A$., 180.09.31.166.1.27.

${ }^{59}$ BCA., 180.09.31.166.1.1.
}

\title{
History Studies
}


Eminliği'ne iki bin lira tahsis edilmiştir. Bu paranın Eminlik bünyesinde oluşturulacak bir komisyon tarafından kullanılması ve satın almaların bu komisyonca resmi olarak yapılması ön görülmüştür. ${ }^{60}$ Ancak İcra Vekilleri Heyeti, Hariciye Vekâleti'nin isteği üzerine Afgan Kralı'nın ülkemize teşrifleri nedeniyle Hükümetçe Kral ve Kraliçeye verilecek hediyelerin, bu hususta zorunlu ya da zorunlu olmayan tüm giderlerin, zamanın az olması nedeniyle pazarlık usulü ile yapılması için gerekli kanuni kolaylığı sağlamıştır. ${ }^{61} \mathrm{Bu}$ karar, alınacak mal ve hizmetlerin süratle yerine getirilmesinde çok büyük kolaylık sağlamıştır. Bu izin doğrultusunda İstanbul'daki satın almalar pazarlık usulü ile Ankara'dan görevlendirilen Uzman Meszaros ve Levazım Memuru Hüsnü Beyler tarafından yapılmıştır. İstanbul Maarif Eminliği tarafından Ankara Maarif Vekâleti'ne gönderilen resmi bir belgede, satın alınan malzemeler hakkında ayrıntılı bilgi mevcuttur: ${ }^{62}$

\begin{abstract}
"1- Etnografya Müzesi için alınacak eşyanın seçimi ve belirlenmesi, Meszaros ve Levazım memuru Hüsnü Bey tarafindan yapılmıştır. Komisyon birçok müessese gezerek, en ucuz yerden alınması sartını getirdiği halde, zamanın pek dar olması nedeniyle ve satın almalardan oluşabilecek en ufak bir gecikmenin dahi müze açılışını etkileyeceğinden, satın almalar isimleri zikredilen kişilerce yapılmıştır. 2- Komisyon satın alınacak koltukların gerek yüzlerinin gerek eșkâlinin resmi dairelere uygun olmasını istediği halde, Meszaros Bey, bunların gayet sade, müzedeki eşyaya aykırı olmaması için sedir biçiminde olanını seçmiştir. Yüzlerini ise Behçet Efendi maroken tavsiye etmesine ră̆men kadife olmasını istediler. 3- Mevzu bahis eşyaların ucuz bilinen müesseselere siparişi istenildiği halde, Meszaros Bey ve Hüsnü Bey birkaç yer dolaştıklarını ve hiç birisinin belirlenen günde veremeyeceği gibi iki bin liraya kadar da fiyat teklif etmişlerdir. Çaresiz Büyük Çarşı'da Yorgancılarda Nuri Efendi adında bir mobilyacı, yirmi altı parça olan takımları ambalajıyla beraber bin yüz seksen liraya yapacağını taahhüt ettiğinden mecburen buraya ihale edilmiştir. 4- Emirleriniz üzerine eşyanın yapıldı ̆̆ yere bizzat gittim. İş̧ilikteki adilik belki şeklinde olabilir, onun dışında resmi bir makama uygun olabilecek surette yapılmaktadır. Kumaşı Meszaros ve Hüsnü Beyler tarafindan Lazari Frango'dan alınmıştır. Bu konuda da mesul ben değilim. 5- Takımların tamamı 13 Mayıs tarihinde sevk edilmiş ve paranın tamamı da aynı tarihte ödenmiştir. Arz ederim efendim."
\end{abstract}

Meszaros ve Hüsnü Beylerin satın almalarda kendi istekleri doğrultusunda hareket etmeleri, İstanbul Maarif Eminliği'ni rahatsız etmiştir. Eminlik, kendilerine sorulmadığından dolayı oluşabilecek hatalı bir durum da mesuliyet kabul etmeyeceklerini dile getirmiştir. İstanbul'dan alınacak malzemeler için toplam bin dokuz yüz doksan dokuz lira on kuruşluk bir harcama yapılmıştır. Malzemeler için ayrılan iki bin liranın, bin yüz seksen lirası altı adet kanepe ve yirmi adet koltuk için harcanmış ${ }^{63}$ ve koltukların Ankara'ya nakledilmesi için de Başağa-zade Nakliye Şirketi'ne seksen sekiz lira otuz beş kuruş ödenmiştir.

Müze binasının çevre düzenlemesi için Arabacı Bayram Ağa'ya on bir mikâp (metre küp) kum için otuz üç lira, müze zemini için Hamamcı-zade Halil Ticarethanesi'ne parke ve muşamba cilası için toplam yetmiş lira altmış kuruş ödenmiştir. ${ }^{64}$ Etnografya Müze Müdürü Hamit Zübeyr Bey tarafından İhzâr Komisyonu Başkanı Rüştü Bey’e gönderilen bir yazıda, müzenin temizliği, eşyaların teşhiri, bazı protokol işleri için eleman ve paraya ihtiyaç olduğu görülmektedir. ${ }^{65} \mathrm{Bu}$ esnada Ressamlar Cemiyeti'nin binanın bu boşluğundan yararlanarak bir resim sergisi açmak için Milli Eğitim Bakanlığı'na müracaat ettiği ve gerekli izni aldığ

${ }^{60} B C A ., 180.09 .31 .166 .1 .61$.

${ }^{61} B C A ., 180.09 .31 .166 .1 .36$.

${ }^{62}$ Avc1, a.g.t., s. 65; BCA., 180.09.31.166.1.31.

${ }^{63} B C A$., 180.09.31.166.1.2.

${ }^{64} B C A ., 180.09 .31 .166 .1 .17$.

${ }^{65}$ Adı geçen yazıda; temizlik ve dikiş işinde kullanılacak kadınların telefon emri ile gönderilmesi, gece çalışmak için karpit lambasına ve iki-üç bayrağa ihtiyaç olduğu, Afgan bayrağının Hariciyeden istendiği ve henüz alınamadığı, hademeler için sırf müzelerde giyilen pullu ve şeritli elbiselerin bulunduğu ve bunların yirmişer liradan satın alınacağı, teşhir edilen eşyaların etiketlerini yazdırmak için bir hattatla pazarlık yapıldığ paraya ihtiyaç bulunduğuna dair bilgiler yer almaktadır. Bkz., BCA., 180.09.31.166.1.19.

\section{History Studies}


görülmektedir. Cumhuriyet dönemi genç ressamları tarafından çizilen ve sanatsal değeri çok yüksek yapıtlardan oluşan Ankara Resim Sergisi, 24 Mayıs 1928'de açılmıştır. ${ }^{66}$

20 Mayıs 1928'de İstanbul'dan Ankara'ya gelen Afgan Kralı Amanullah, eşi Kraliçe Süreyya, Prens Nurissırac, Prenses Huriye Tarzî ve Mesaib-i Serdar Hasan Han, 25 Mayıs 1928'de Cumhurbaşkanı Gazi Mustafa Kemal Paşa ile birlikte Etnografya Müzesi'nde açılan resim sergisini gezmişlerdir. ${ }^{67}$ Bu esnada Afgan Kralı ve eşinin, Nazmi Ziya Bey, Ali Rıza Bey, Hikmet Bey, Şevket Bey, Nazmi Bey, Namık İsmail Bey, Sami Bey ve Güzin Feyhaman Hanım'ın eserlerini çok beğenerek satın almaları, resim sanatımızın kısa sürede geldiği noktayı vurgulaması açısından son derece önemlidir. 25 Mayıs 1928'de yapılan bu etkinlikle, Ankara Etnografya Müzesi’nin yalnızca "Resim Heykel Müzesi” olarak açılışı yapıllmıştır. Afgan Kralının ziyareti sırasında dönemin basınına yansıyan haberler de bu bilgiyi doğrulamaktadır. ${ }^{68}$

Ankara Etnografya Müzesi'nin resmi açılış tarihi, 18 Temmuz 1930'dur. Kültür, sanat ve eğitim alanında önemi son derece büyük olan Etnografya Müzesi, açıldığından itibaren bünyesinde çok değişik koleksiyonları barındırmıştır. Müze binasının inşaatı devam ederken başlangıçta ne müzesi yapılacağına dair fikir karışıklığı, eserler toplanırken de yaşanmış ve tarihi değer taşıyan ve sanatsal özelliği olan her türlü eşyanın Ankara'da toplanması, müze koleksiyonlarının çeşitliliğini artırmıştır. Ankara Etnografya Müzesi'nde, Türk sanatının Selçuklu Devri'nden günümüze kadar devam eden pek çok örnekleri sergilenmektedir: ${ }^{69}$

\begin{abstract}
“Anadolu'nun çeşitli yörelerinden derlenmiş etnografik malzemeler (halk giysileri, süs eşyaları, çeşitli yörelerden halı ve kilimler vs.); Anadolu maden sanatını temsil eden çok çeşitli eserler; Osmanlı dönemi savaş aletleri; Türk çini porselenleri; tasavvuf ve tarikatlarla ilgili eşyalar; Türk yazı sanatı ve ağaç işçiliklerinden örnekler vs.”.
\end{abstract}

Müze bünyesi içerisinde Irkiyat Şubesi, Folklor Şubesi, Resim heykel Şubesi, İnkılap Şubesi ve Anadolu etnografya, folklor ve sanat tarihiyle ilgili eserleri içeren bir ihtisas kütüphanesi bulunmaktadır. Müze binasının zamanla fiziksel açıdan yetersiz kalması, müze koleksiyonlarından bazılarının diğer müzelere taşınmasını zorunlu kılmıştır. Özellikle Resim Heykel Şubesi için toplanan eserler Gazi Eğitim Enstitüsü’ne ve İnkılap Şubesi için toplanan eserler ise Türk İnkılâp Tarihi Enstitüsü’ne devredilmiştir. ${ }^{70} 15$ Nisan 1942 tarihinde 4204 sayılı yasa ile DTCF bünyesi içerisinde kurulan Enstitüye teslim edilen eserler arasında, 23 Nisan 1920'de TBMM'nin kapısına asılan bayrak; 23 Aralık 1930'da Menemen'de şehit edilen Kubilay'ın kasketi; Atatürk'ün Sivas'ta kullandığı yazıhane ve koltuk; Hatay Devleti'nin idari işlerinde kullanılan mühür vs. yer almaktadır.

Ankara Etnografya Müzesi, Türk sanatına ait sosyal ve kültürel eserlerin depolandığı ve örneklerinin sergilendiği bir müze olmasının yanı sıra 15 yıl da Anıtkabir işlevini yerine getirmiştir. 10 Kasım 1938'de İstanbul'da hayata gözlerini kapayan Türkiye Cumhuriyeti Devleti'nin kurucusu Büyük Önder Gazi Mustafa Kemal Paşa'ya ev sahipliği yapmıştır. Atatürk'ün Naaşı, 20 Kasım'da İstanbul'dan Ankara'ya getirilmiş ve 21 Kasım 1938'de

\footnotetext{
${ }^{66}$ Halil Özyiğit, "Osmanlı'dan Cumhuriyet'e Geçiş Sürecinde Basında Resim Eleştirisi”, Pamukkale Üniversitesi Sosyal Bilimler Enstitüsü Dergisi, Say1 27, Mayıs 2017, s. 192.

${ }^{67}$ Sükan, Bige; Aysal, Necdet, Türk Inkalâp Tarihi Enstitüsü Arşivi Fotoğraflartyla Atatürk ve Cumhuriyet (19231938), Ankara Üniversitesi Basımevi, Ankara 2013, s. 61-63.

${ }^{68}$ Hâkimiyet-i Milliye, "Afgan Kralı Hazretleri Dün Sanayi Nefise Sergisini Ziyaret Ettiler. Eserleri Takdir Buyurdular ve Bazılarını Satın Aldılar”, 26 Mayıs 1928, Cumartesi, s. 1; Hâkimiyet-i Milliye, “Afgan Kraliçesi Hazretleri Resim Sergisinde”, 27 Mayıs 1928, s. 1; Özyiğit, a.g.m., 192-193.

69 1930'larda Ankara'da iktidara yakın aydınlara dair gözlemler hakkında bkz: Hasan Dinçer; Niyazi Berkes'e Göre Kemalizm ve Çağdaşlaşma, (Ankara Üniversitesi Türk İnkılap Tarihi Enstitüsü, Yayınlanmamış Doktora Tezi), Ankara 2012, s. 16-18; Tasouji, a.g.m., s. 139-140.

70. Necdet Aysal, “Ankara Üniversitesi Türk İnkılâp Tarihi Enstitüsü Tarihçesi ve Gelişim Süreci”, Atatürk Yolu Dergisi, Ankara Üniversitesi Türk İnkılâp Tarihi Enstitüsü, Sayı 33-34, Mayıs-Kasım 2004, s. 243.
}

\title{
History Studies
}


Müze'nin iç avlusunda hazırlanan geçici kabrine konulmuştur. ${ }^{71}$ Müze, Naaşı 10 Kasım 1953 'te Anıtkabir'e nakline kadar devlet başkanlarının, yabancı heyetlerin ve halkın ziyaret yeri olmuştur.

\section{Sonuç}

Ulusal Bağımsızlık Savaşı'nın devam ettiği günlerde Ankara'da Maarif Kongresi'ni toplayan Mustafa Kemal Paşa, gerçek anlamda kurtuluşun eğitim alanında yapılacaklar ile mümkün olacağını işaret etmiş̧tir. Bu düşünce ile muasır medeniyetler seviyesine çıkmış çağdaş bir Türkiye inşa etmek için devlet organizasyonunda ve toplum yapısında köklü devrimler yapılmıştır. Yönetim, ekonomi, hukuk, eğitim... Hâsılı bütün toplumsal hayata yepyeni bir yön verilirken, Türk toplumunda da gerçekleştirilen üst yapı değişiklikleri ile uyumlu ve çağdaş dünyada ayakta kalmayı sağlayacak bir anlayış, zihniyet yaratılmaya çalışılmıştır. Çağdaş Türk kültürünün ortaya konulabilmesi için yararlanılacak bilimsel alan ise etnografya olmuştur. Etnografya Müzesi'nin açılışı bu çerçevede atılan bir adımdır. Son yüz elli yılın savaşları ve acıları ile yorgun, içe kapalı ve kaderci bir hayat anlayışına sahip Türk toplumu, Etnografya Müzesi ile yabancı kaldığı ya da Hıristiyan işi gözüyle baktığı, resim ve heykel gibi sanat dalları ile bu müze vasıtasıyla yakınlık kuracaktır.

Milli Mücadele yıllarında tarihi bir görev üstlenerek ülkenin kaderini değiştiren Ankara'da, kutsal bir mekân olan Namazgâh Tepesi'nde başlayan Etnografya Müzesi çalışmalarına, birçok tanınmış eğitimci ve sosyal bilimci katkı sağlamıştır. Müze binası, Türk mimar ve müteahhitler tarafından yapılmıştır. Dönemin bütün olumsuz koşullarına rağmen tamamlanan bina, Anadolu'nun mimari birikimini yansıtmaktadır. Müzelerin, akıp giden zaman içinde, toplumların ortaya koyduğu eserleri sergileyerek bireyleri zaman, farklılık, uygarlık, değişme, konularında tefekküre sevk etmeyi böylece bir bilinç oluşturmayı amaçladığ 1 malumdur. Bu açıdan bakılınca, envanteri itibarıyla, Etnografya Müzesi'nin Türk insanını, kendi tarihsel seyri üzerine düşündürmeyi, dikkatini değişimin sürekliliğine çekmeyi de amaçladığı aşikârdır. Bu, Türkiye Cumhuriyeti Devleti'nin Batı uygarlığının parçası olma kararlılığıla da anlamlı bir bütün oluşturmaktadır.

Etnografya Müzesi'ni diğer müzelerden farklı kılan başlıca özellik ise Atatürk'ün naaşına uzunca bir süre ev sahipliği yapmasıdır. Cumhuriyet'in, eğitim ve kültür alanlarındaki yöneliş ve eylemleri bütün olarak değerlendirildiğinde; uygarlığ ve Türk toplumunu uygarlı̆ga katkı yapabilecek düzeye çıkarma hedefi belirmektedir ki, Etnografya Müzesi'nin kuruluşu da bu yolda atılmış kıymetli bir adımdır.

\section{Kaynakça}

\section{Arşivler}

Ankara Üniversitesi Türk İnkllap Tarihi Enstitüsü Arşivi (TiTE), FK76, G2, B2-141001.

Başbakanlık Cumhuriyet Arşivi (BCA), 30. 18. 01. 01. 21. 67. 14.

BCA., 30. 18. 01.01.22.76. 17.

BCA., 30.18.01.01.21.67.9.

$B C A ., 30.18 .1 .1 .22 .76 .17$.

$B C A$., 180.09.31.166.1.53.

BCA., 180.09.31.166.1.64.

${ }^{71}$ Tasouji, a.g.m., s. 139-140. 


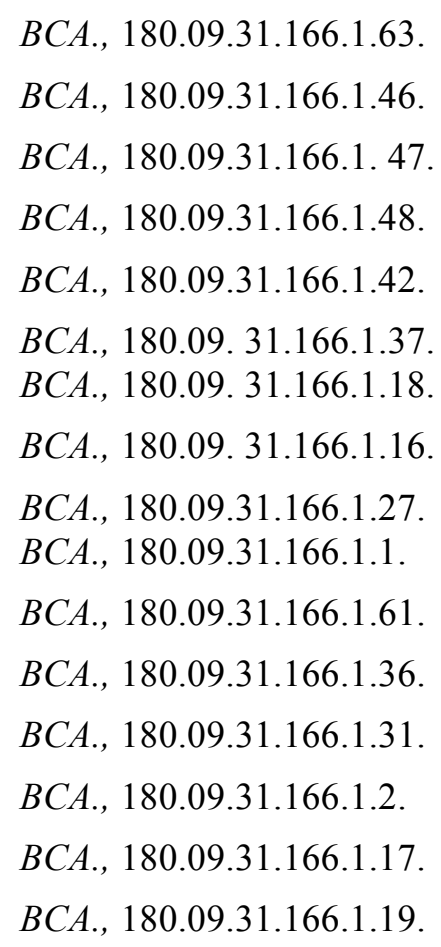

\section{Kitaplar}

CAN, Şefik, Klasik Yunan Mitolojisi, İnkılâp Kitabevi, İstanbul 1994.

Cumhurbaşkanları, Başbakanlar ve M.E. Bakanlarının Milli Eğitimle İlgili Söylev ve Demeçleri, Milli Eğitim Basımevi, Ankara 1946.

FIRAT İNCİ, Nurcan, Ankara'da Cumhuriyet Dönemi Mimarisinden İki Örnek Etnografya Müzesi ve Eski Türk Ocağı Merkezi Binası, Türk Tarih Kurumu Basımevi, Ankara 1998.

GERÇEK, Ferruh, Türk Müzeciliği, Kültür Bakanlığı Yayınları, Ankara 1999.

KARADUMAN, Hüseyin, Ulus-Devlet Bağlamında Belgelerle Ankara Etnografya Müzesi'nin Kuruluşu ve Milli Müze, Bilgin Kültür Sanat Yayınları, Ankara 2016.

KURUYAZICI, Hasan, Osmanlı'dan Cumhuriyet'e Bir Mimar Arif Hikmet Koyunoğlu Anılar, Yazılar, Mektuplar, Belgeler, Yapı Kredi Yayınları, İstanbul 2008.

OĞAN, Aziz, Türk Müzeciliğinin 100'üncü Yıldönümü, Türkiye Turing ve Otomobil Kurumu, İstanbul 1947.

ÖZ, Tahsin, Ahmet Fethi Paşa ve Müzeler, Milli Eğitim Basımevi, İstanbul 1948.

SÜKAN, Bige-Necdet Aysal, Türk İnkllâp Tarihi Enstitüsü Arşivi Fotoğraflarlyla Atatürk ve Cumhuriyet (1923-1938), Ankara Üniversitesi Basımevi, Ankara 2013.

ŞAPOLYO, Enver Behnan, Müzeler Tarihi, Remzi Kitabevi, İstanbul 1936.

ŞİMŞİR, Bilal N., Atatürk ve Afganistan, Avrasya Stratejik Araştırmalar Merkezi Yayınları, Ankara 2002.

TEKİNER, Ü. Aylin, Atatürk Heykelleri, Kült, Estetik, Siyaset, İletişim Yayınları, İstanbul 2010. 
TUNAYA, Tarık Zafer, Türkiye'de Siyasal Partiler, Cilt,1, İletişim Yayınları, İstanbul 2015.

ÜLKÜTAŞIR. M. Şakir, Cumhuriyet'le Birlikte Türkiye'de Folklor ve Etnografya Çalışmaları, Başbakanlık Basımevi, Ankara 1972.

ÜSTEL, Füsun, Imparatorluktan Ulus-Devlete Türk Milliyetçiliği Türk Ocaklarl, İletişim Yay, İstanbul 2004.

\section{Makaleler}

“Ankara'da Teessüs Edecek Olan Halk Müzesi Hakkında Birinci Rapor”, Maarif Vekâleti Mecmuası, Sayı 1, İstanbul 1 Mart 1341, s. 9-20.

“Ankara'da Teessüs Edecek Olan Halk Müzesi Hakkında İkinci Rapor”, Maarif Vekâleti Mecmuası, Sayı 4, İstanbul 1 Eylül 1341, s. 1-15.

ACIPAYAMLI, Orhan, "Türkiye'de Etnografi Araştırmaları", Etnografya ve Bilimsel Filmler Sempozyumu, 11-13 Nisan 1973, Avusturya Kültür Yayınları, İstanbul 1973, s. $1-15$.

AYSAL, Necdet, "Atatürk Dönemi Türk Devrimi”, Başlangıcından Günümüze Türkiye Cumhuriyeti Tarihi, (Editör, Prof. Dr. Temuçin Faik Ertan), 6. B., Siyasal Kitabevi Yay., Ankara 2018, s. 181-207.

"Ankara Üniversitesi Türk İnkılâp Tarihi Enstitüsü Tarihçesi ve Gelişim Süreci”, Atatürk Yolu Dergisi, Ankara Üniversitesi Türk İnkılâp Tarihi Enstitüsü, Say1 33-34, Mayıs-Kasım 2004, s. 241-263.

BAYRAM, Sadi, "Hamit Zübeyr Koşay’dan Anekdotlar”, Türk Kültürü Araştırmalart Dergisi, Türk Kültürü Araştırma Enstitüsü, C. XXIV, Sayı 2, 1986, s.10-20.

BİRKAN, Güven-Selçuk Pehlivanlı, "Mimar Arif Hikmet Koyunoğlu ile Bir Söyleşi”, Mimarlı Dergisi, Mimarlar Odas1, Say1, 150, İstanbul 1977, s. 8-16.

CANTEK, Levent, "Kolektif Kimliğin İnşasında Halk Terbiyesi ve Ritüellerin Medya Metinlerine Dönüştürülmesi”, Folklor/Edebiyat, Uluslararası Hakemli Dergi Cilt V, Sayı 20, Ankara 1999, s., 5-14.

ÇAL, Halit, “Osmanlı'dan Günümüze Türkiye'de Müzeler”, Türkiye Araştırmalarl Literatür Dergisi, Cilt 7, Sayı 14, 2009, 315-333.

ÇİFTÇİ, Kemal, “Tarih Kimlik ve Türkiye'nin Belleğinin Dış Politikası”, Akademik İncelemeler Dergisi, Sakarya Üniversitesi Sosyal Bilimler Enstitüsü, Cilt 2, Say1 1, Sakarya 2007, s. 97-131.

GÜZEL, Abdürrahim, "İlk Heyeti ilmiye Çalışmaları, Alınan Kararlar ve Dini Tedrisat", Erciyes Üniversitesi İlahiyat Fakültesi Dergisi, Sayı, 4, Kayseri 1987, s. 337-356.

HÜLÜR, Himmet-Gürsoy Akça, "İmparatorluktan Cumhuriyete Siyasal Bütünlük ve Ulusalcılık Söylemi”, Selçuk Üniversitesi Türkiyat Araştırmaları Dergisi, Sayı 22, Konya 2007, s. 311-335.

KARADUMAN, Hüseyin, "Türk Ocakları ve Hars Müzeleri”, Vakıflar Dergisi, Vakıflar Genel Müdürlüğü Yayınları, Sayı 30, Ankara 2007, s. 503-518.

KOŞAY, Hamid Zübeyr, “1927'de Etnografya Cemiyeti Kurma Teşebbüsü”, Çığır Dergisi, Genç Türk Edebiyat Cemiyeti, Sayı 127, Ankara 1943. 
NAMAL, Yücel, "Macar Türkolog Gyula Meszaros ve Türkiye'deki Çalışmaları”, XI. Milli Türkoloji Kongresi Bildiri Kitabı, C. 2, İstanbul Büyükşehir Belediyesi Kültür Daire Başkanlığı Yayınları, İstanbul 2015, s. 621-653.

“Osman Hamdi”, Hürriyet Gösteri Sanat Dergisi, Hürgün Gazetecilik ve Matbaacılık A.Ş., İstanbul 1990, s. 1-32.

ÖZYİĞİT, Halil, “Osmanlı'dan Cumhuriyet'e Geçiş Sürecinde Basında Resim Eleştirisi”, Pamukkale Üniversitesi Sosyal Bilimler Enstitüsü Dergisi, Sayı 27, Mayıs 2017, s. 174196.

SERBESTOĞLU, İbrahim; Turan Açık, “Osmanlı Devleti’nde Modern Bir Okul Projesi: Müze-i Hümâyûn Mektebi”, Gazi Akademik Bakış, Cilt 6, Sayı 12, Yaz 2013, s. 157172.

SUNBAS, Ahu, "Türk Modernleşmesini Ankara Palas Üzerinden Okumak: Doğu'dan Batı'ya Açılan Bir Pencere", H.Ü. İktisadi ve İdari Bilimler Fakültesi Dergisi, Cilt 31, Say1 1, 2013, s. 171-198.

TASOUJI, Canan Dural, "Bir Hafıza Mekânı Olarak Müze: Ankara Etnografya Müzesi”, Karadeniz Teknik Üniversitesi İletişim Araştırmaları Dergisi, Yıl 3, Sayı 5-6, s. 129143.

ORAL, Mustafa, “Ankara Etnografya Müzesi İnkılâp Şubesi”, Atatürk Yolu Dergisi, Ankara Üniversitesi Türk İnkılâp Tarihi Enstitüsü, Sayı 29-30, Mayıs-Kasım 2002, s. 117-130.

\section{Gazeteler}

Volume 11

Issue 5

October

2019

"Hars Encümeni Raporu”, Hâkimiyet-i Milliye, 6 Ağustos 1923, s. 1-3.

"Afgan Kralı Hazretleri Dün Sanayi Nefise Sergisini Ziyaret Ettiler. Eserleri Takdir Buyurdular ve Bazılarını Satın Aldılar”, Hâkimiyet-i Milliye, 26 Mayıs 1928, s. 1.

“Afgan Kraliçesi Hazretleri Resim Sergisinde”, Hâkimiyet-i Milliye, 27 Mayıs 1928, s. 1.

\section{Tezler}

AVCI, Ahmet, Cumhuriyet Dönemi Etnografya Çalışmalarına Bir Örnek: Ankara Etnografya Müzesi, (Ankara Üniversitesi Türk İnkılap Tarihi Enstitüsü, Yayınlanmamış Yüksek Lisans Tezi), Ankara 2017.

DİNÇER, Hasan, Niyazi Berkes'e Göre Kemalizm ve Çağdaşlaşma, (Ankara Üniversitesi Türk İnkılap Tarihi Enstitüsü, Yayınlanmamış Doktora Tezi), Ankara 2012.

\section{Sözlükler}

EMİOĞLU, Kudret - Aydın, Suavi, Antropoloji Sözlüğ̈̈, Bilim ve Sanat Yayınları, Ankara 2003.

ÖRNEK, Sedat Veyis, Etnoloji Sözlüğü, Ankara Üniversitesi Dil ve Tarih Coğrafya Fakültesi Yayınları, Ankara 1971.

\section{İnternet Kaynakları}

T.C. Kültür ve Turizm Bakanlığ Ankara Etnografya Müzesi, http://www.etnografyamuzesi.gov.tr/. (Erişim tarihi: 10.08.2019).

T.C. Kültür ve Turizm Bakanlı̆̆l, http://www.kultur.gov.tr/TR-96354/ankara-etnografyamuzesi.html. (Erişim tarihi: 10.08.2019). 


\section{EKLER}

\section{EK-1}

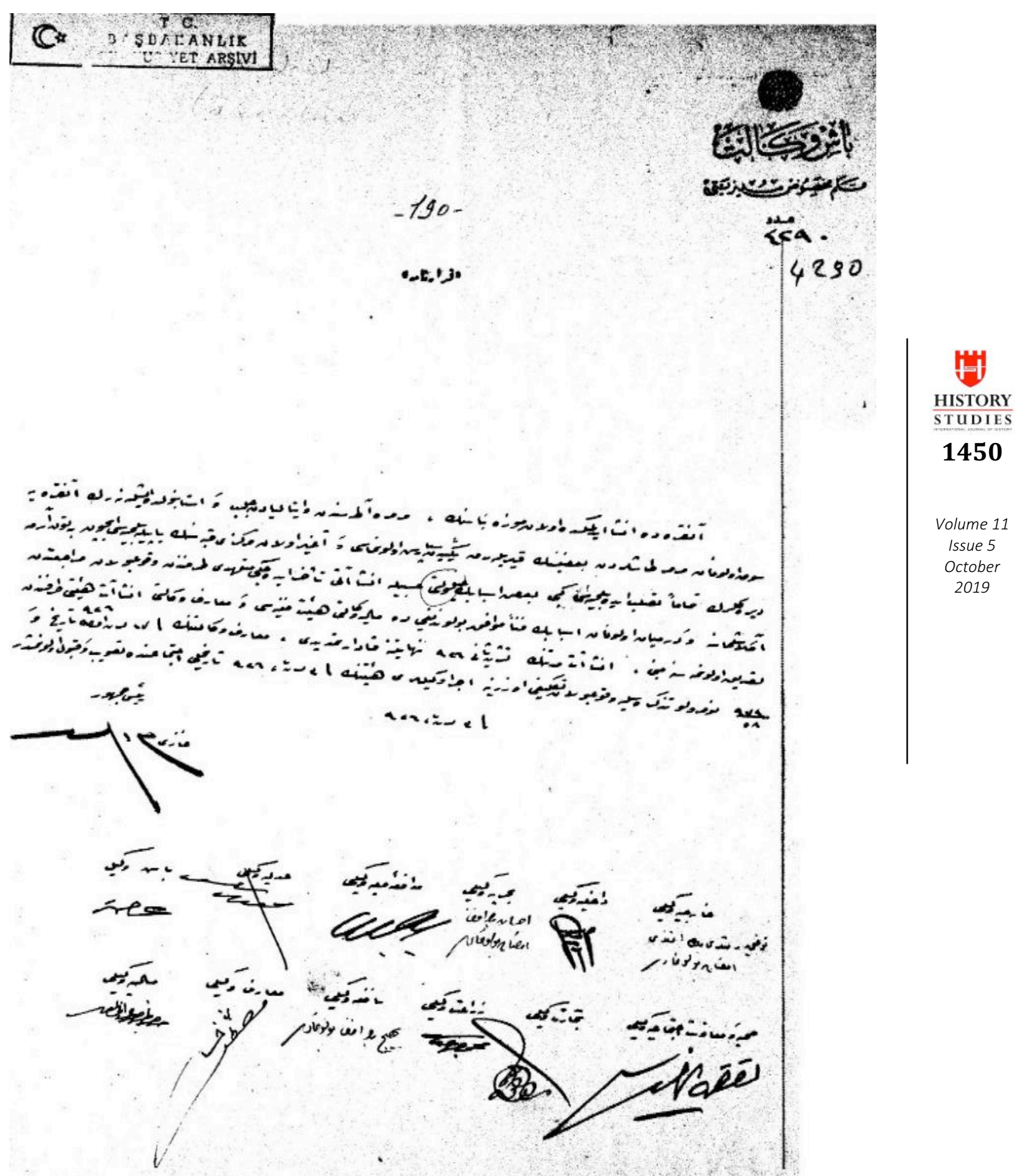


Başbakanlık Cumhuriyet Arşivi, 30.18.01.01.21.67.14.

\section{EK- 2}
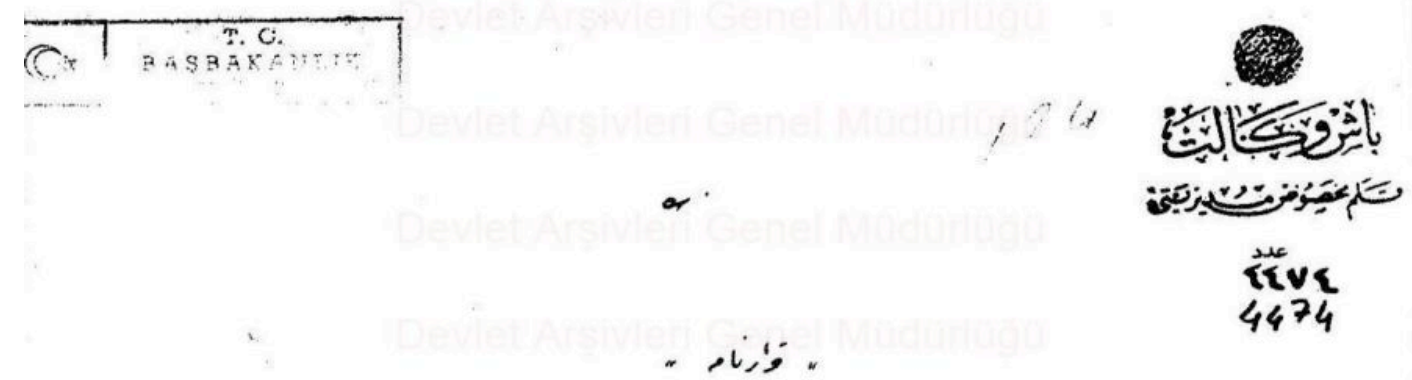

l

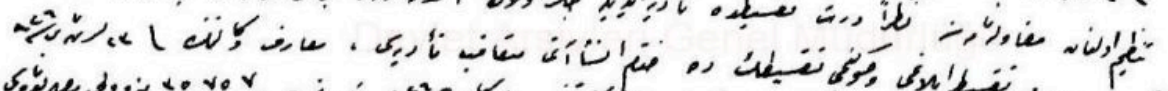

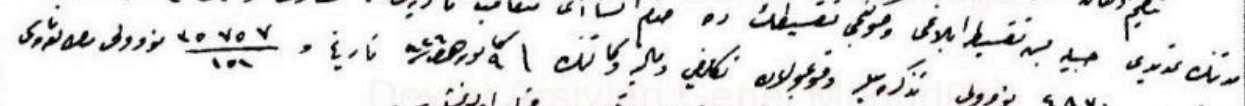
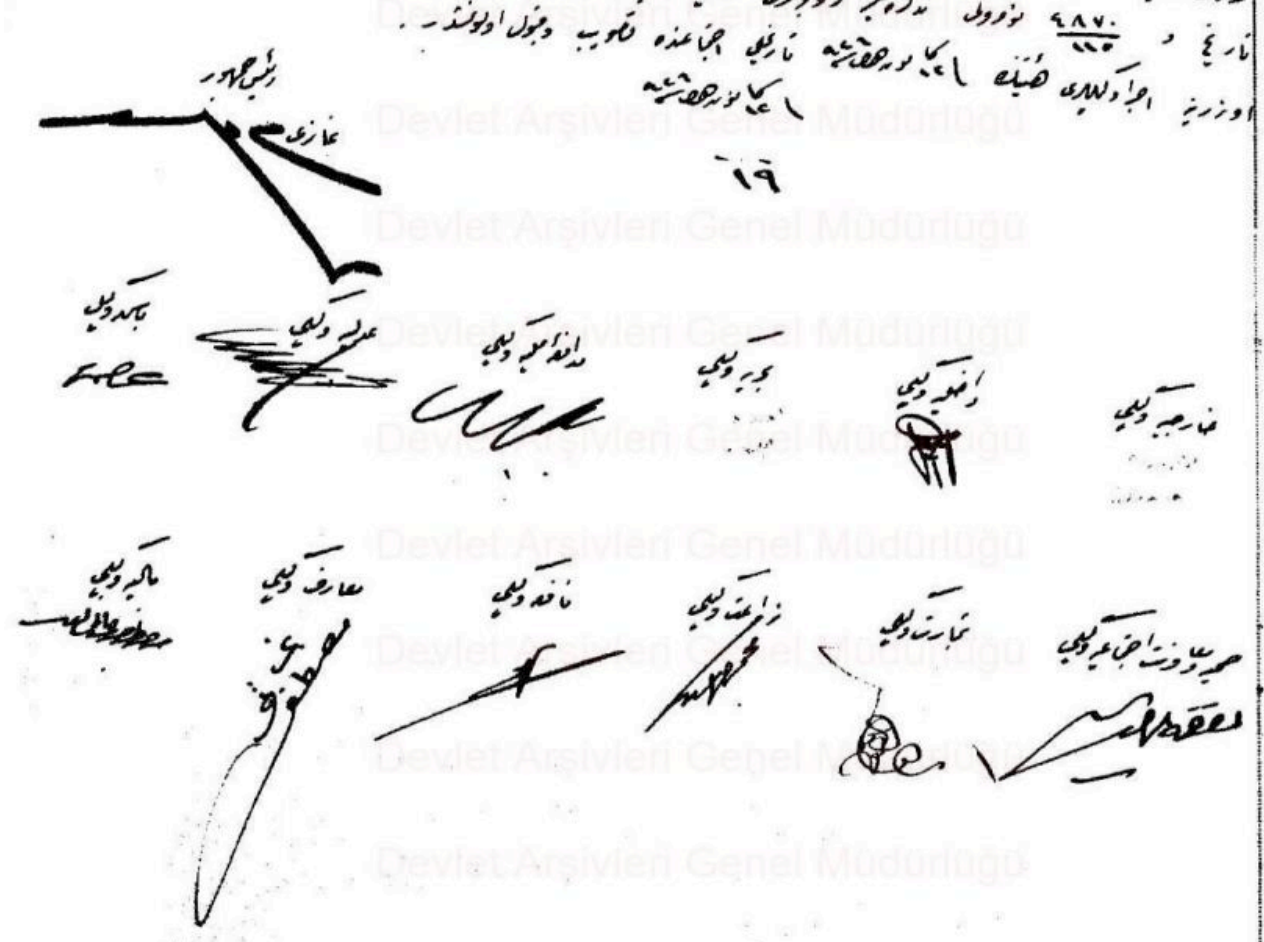
EK- 3

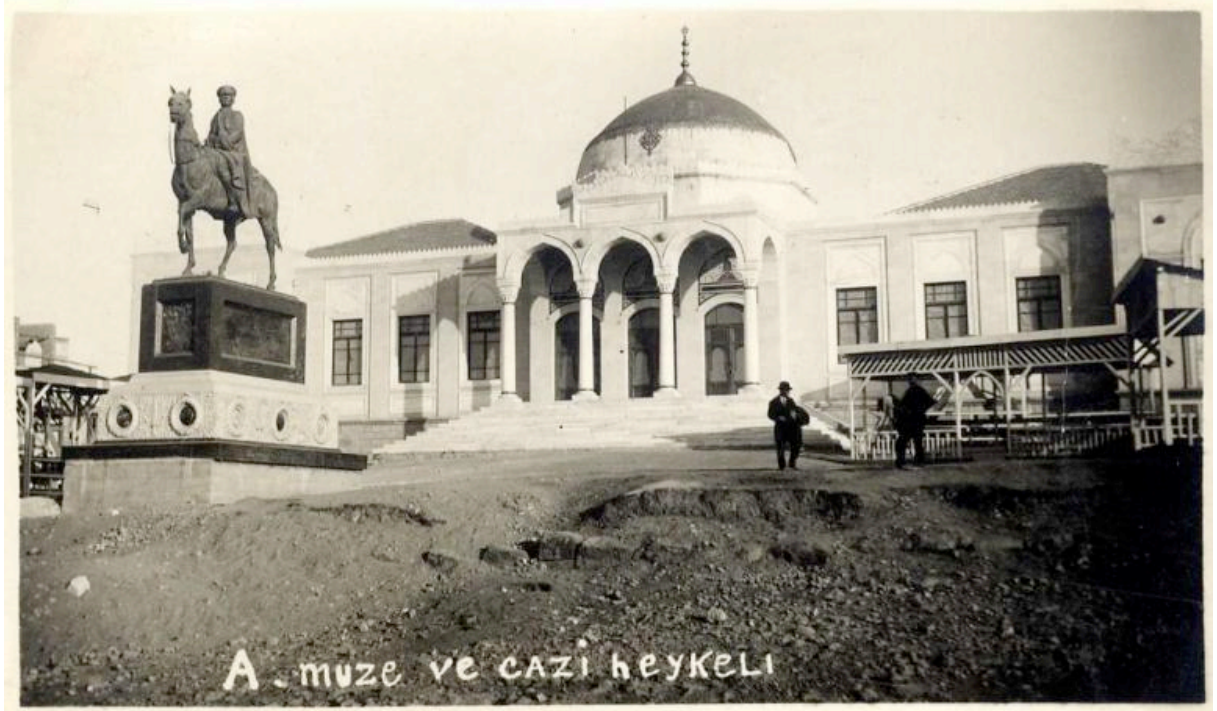

Ankara Üniversitesi Türk İnkılap Tarihi Enstitüsü Arşivi, FK76, G2, B2-141001.

EK-4

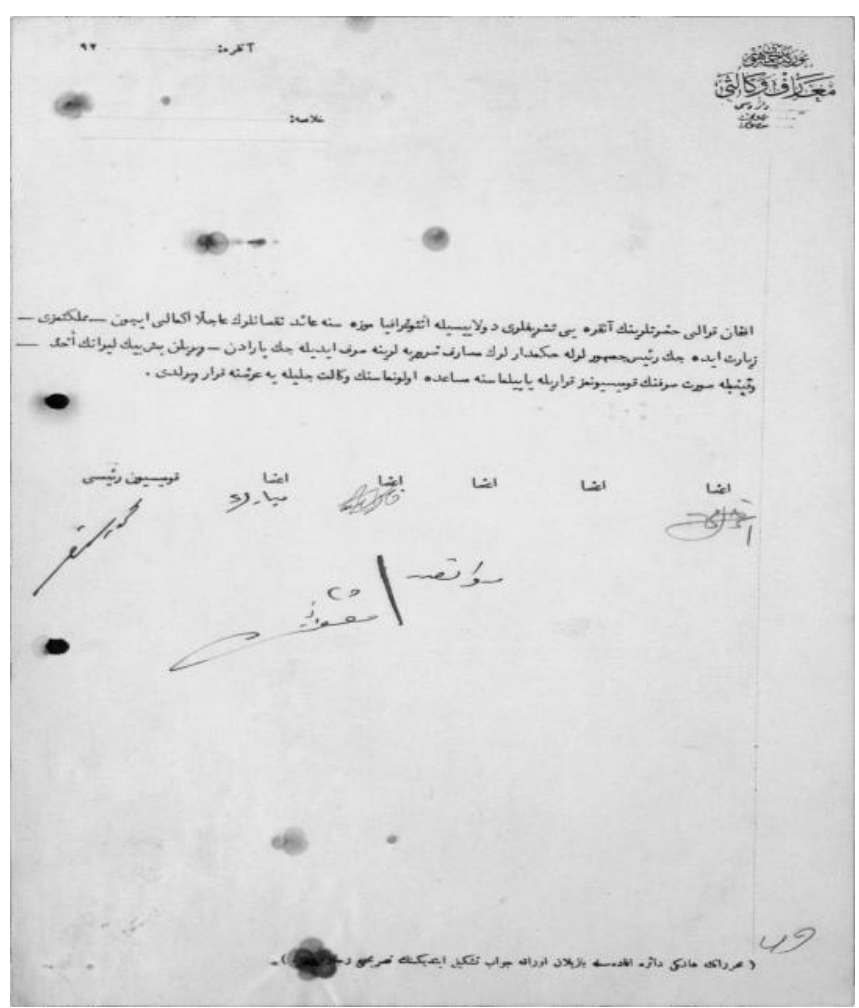

Volume 11

Issue 5

October

2019

Başbakanlık Cumhuriyet Arşivi, 180.09.31.166.1.53. 
EK-5

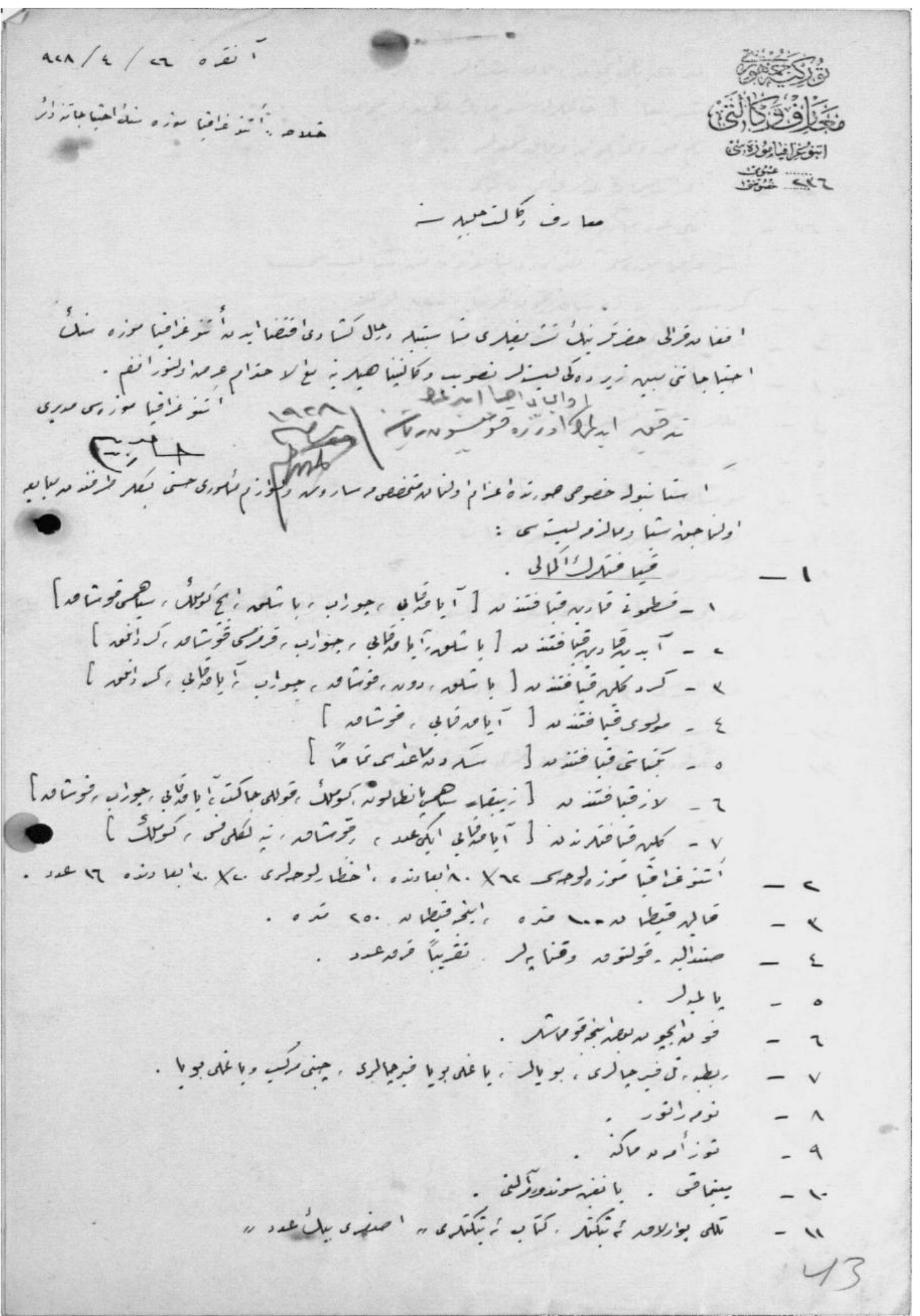

Başbakanlık Cumhuriyet Arşivi. 180.09.31.166.1.46

\section{History Studies}




\section{EK-6}

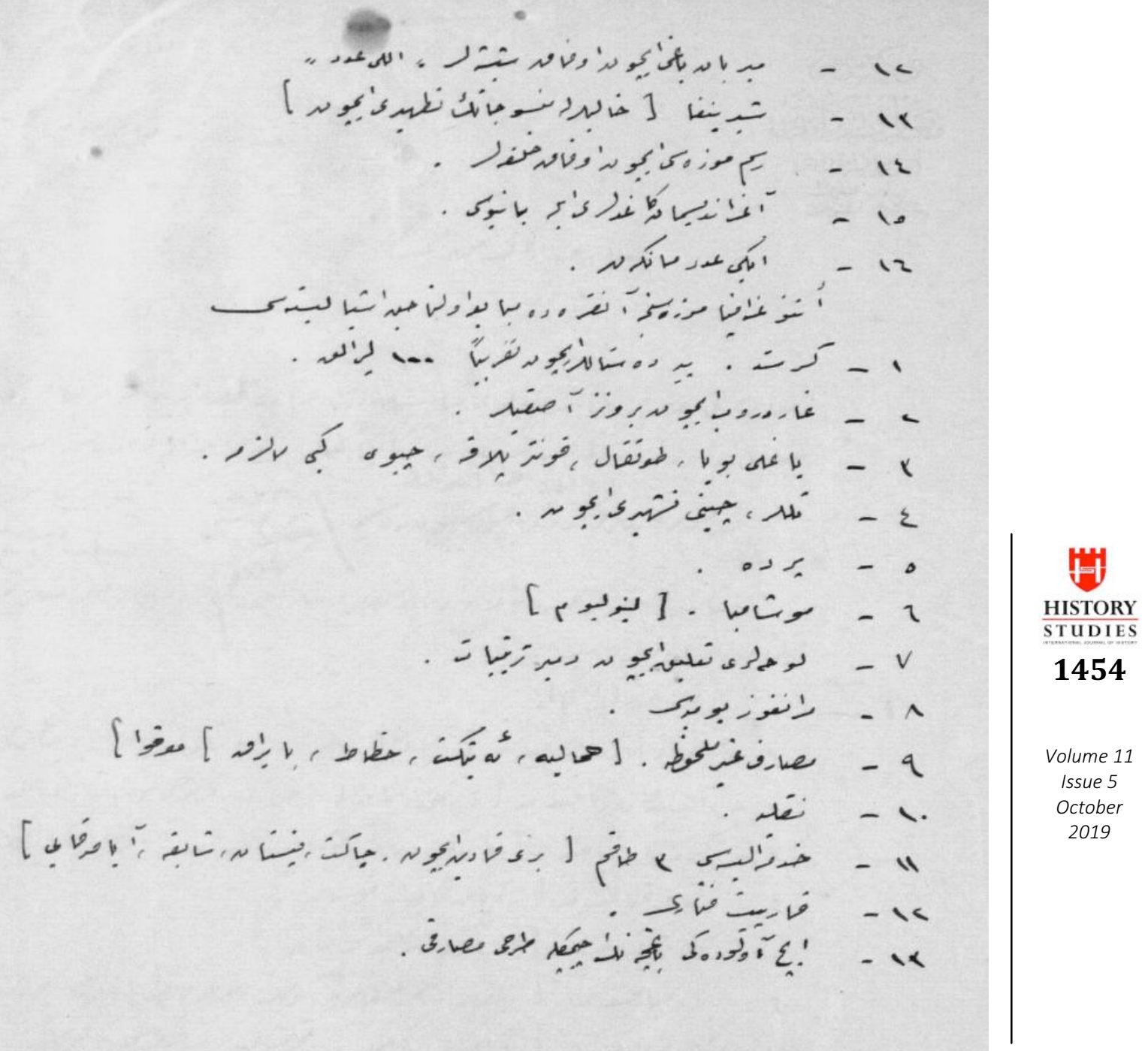

Başbakanlık Cumhuriyet Arşivi. 180.09 .31 .166 .1 .47 
EK-7

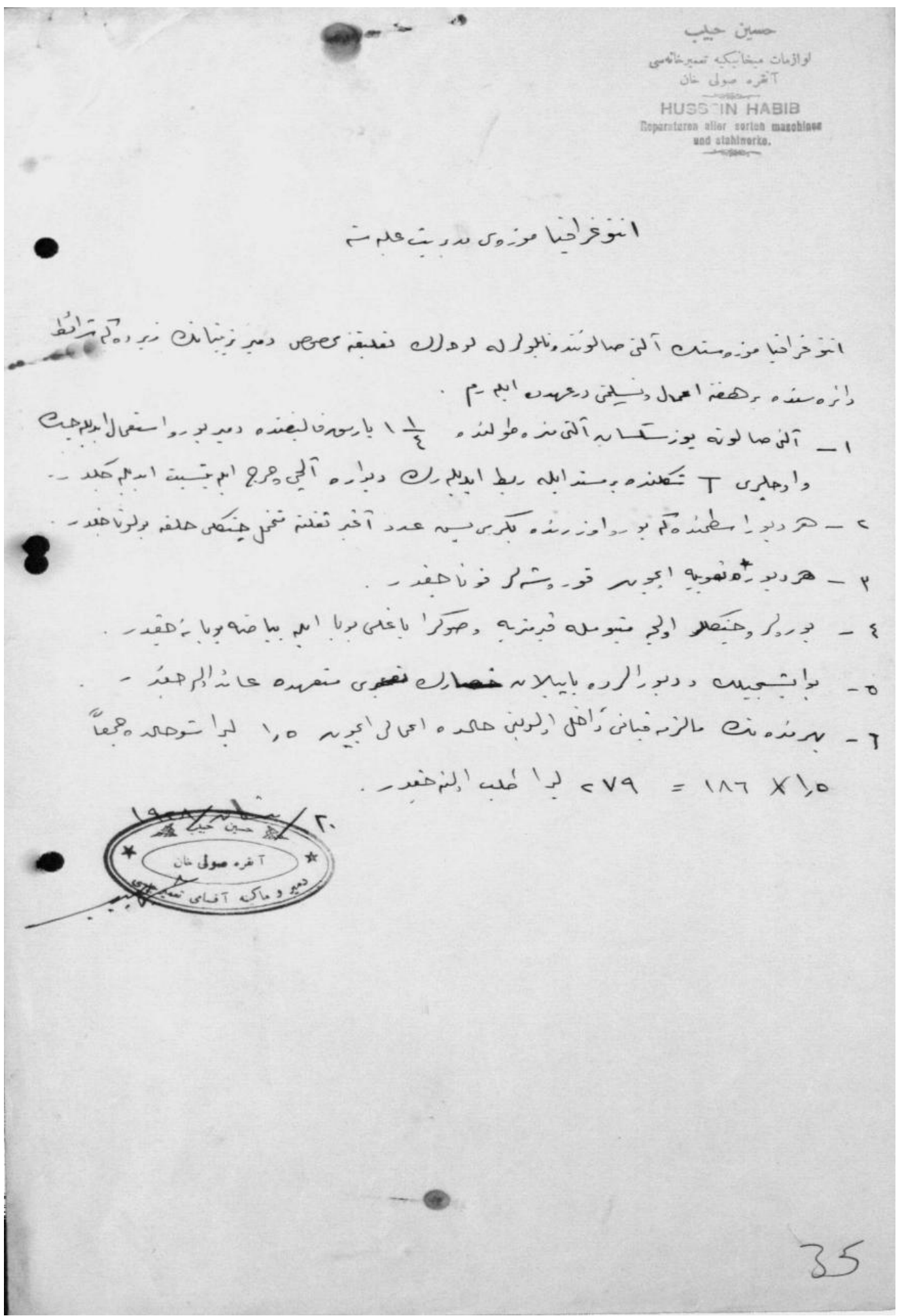

Başbakanlık Cumhuriyet Arşivi, 180.09.31.166.1.37.

\section{History Studies}

